\title{
ANALISIS SISTEM AKUNTANSI PEMERINTAH PUSAT (SAPP) DI KANTOR AKUNTANSI REGIONAL JAKARTA
}

\author{
Titis Wahyuni ${ }^{*}$ \\ ${ }^{'}$ Program Studi Akuntansi Program Vokasi Universitas Indonesia
}

\begin{abstract}
ABSTRAK - Penelitian ini dimaksudkan untuk menggambarkan Sistem Akuntansi Pemerintah Pusat (SAPP) yang dilaksanakan oleh Badan Akuntansi Keuangan Negara (BAKUN) melalui Kantor Akuntansi Regional (KAR) yang terdapat di berbagai daerah di lndonesia serta hasil-hasil yang diharapkan dari Sistem Akuntansi Pemerintah Pusat. Dalam sistem akuntansi, laporan keuangan yang dihasilkan bergantung pada keakuratan dan validitas input data transaksi. Dengan demikian keakuratan dan validitas dari laporan keuangan pemerintah yang dihasilkan akan bergantung pada kualitas kerja yang dilakukan oleh KAR dalam mengelola input data transaksi keuangan pemerintah. Metode yang digunakan dalam penelitian ini adalah dengan menganalisis masalah-masalah/ kendala-kendala yang dihadapi oleh KAR Jakarta dan juga menganalisis proses yang dilaksanakan oleh KAR Jakarta pada tahun 2000-2001. Analisis dilakukan pada subsistem pengolahan data transaksi penerimaan (Cash Receipt) dan pengeluaran kas pemerintah (Cash Disbursement) serta subsistem buku besar (General Ledger) dengan menggunakan Analysis Critical Success Factor (CSF), Performance Grid, Proses Modeling, Data Modeling, and Network Modeling. Hasil penelitian menunjukkan bahwa terdapat beberapa masalah/kendala yang dihadapi oleh KAR dalam mengelola data transaksi keuangan pemerintah. Kemudian, dengan menggunakan hasil penelitian dilakukan usaha-usaha untuk memperbaiki sistem yang sedang berjalan.
\end{abstract}

Kata kunci: SAPP, KAR, process modeling, data modeling, critical success factor.

ABSTRACT - This research is intended to describe Central Government Accounting System (SAPP) implemented by the State Financial Accounting Agency (BAKUN) through The Regional Accounting Office (KAR) and the expected outcomes of Central Government Accounting System. In a accounting system, financial statements generated rely on the accuracy and validity of data input transactions. The accuracy and validity of the Government's financial statements generated will depend on the quality of the work done by KARs in managing the Government's financial transaction data input.

The method usedin this research isby analyzing the problems/obstaclesfaced by KAR Jakarta and also analyzing the process performed by KAR Jakarta during 2000 - 20001. Analysis was performed on cash receipt transactiondata processingsubsystem (Cash Receipt) and governmentcashexpenditures (Cash Disbursement), and general ledger subsystem (General Ledger) used and done by using Analysis Critical Success Factor (CSF), Performance Grid, Proses Modeling, Data Modeling, and Network Modeling. The result of this research shows that there are some problems/obstacles faced by KAR in managing data of financial transactions of the Government. By using these results are then made efforts to repair the running system.

Keywords: Central Government Accounting System, Regional Accounting Office, Central Accounting System, process modeling, data modeling, critical success factor. 


\section{PENDAHULUAN}

\section{Latar Belakang}

Kondisi perekonomian lndonesia yang semakin memburuk akibat gejolak politik yang tak kunjung selesai memaksa pemerintah untuk mencari dukungan dana dari luar negeri untuk membiayai negara ini. Dengan tingkat inflasi yang tinggi serta defisit anggaran yang dialami oleh pemerintah lndonesia dan masalah-masalah lain yang dialami oleh pemerintah, maka dibutuhkan suatu sistem informasi yang dapat memantau kinerja pemerintah (terutama yang berkaitan dengan bidang ekonomi) sehingga krisis ekonomi yang melanda Indonesia dapat diperbaiki sedikit demi sedikit atau setidaknya tidak semakin memburuk. Sistem informasi tersebut diharapkan dapat memberikan informasi lengkap mengenai kondisi perekonomian lndonesia saat ini seperti berapa aset, hutang, pendapatan, dan biaya yang terjadi layaknya sebuah neraca serta informasi penting lainnya. Dengan menggunakan sistem informasi ini kinerja pemerintah dapat dipantau dan pemerintah juga dapat mengambil langkah-langkah yang tepat dan konkrit dalam memperbaiki kondisi perekonomian negara ini.

Sebenarnya pemerintah sudah memiliki Sistem Akuntansi Pemerintah Pusat (SAPP) untuk menata administrasi negara. SAPP telah dikembangkan dan diimplementasikan secara bertahap. Tahap pertama dilaksanakan mulai tahun anggaran 1993/1994 dan pada tahun anggaran 1999/2000 telah mencakup seluruh Departemen/Lembaga diseluruh propinsi. SAPP adalah suatu sistem terpadu yang menggabungkan prosedur manual dan proses elektronis untuk mengambil data, membukukan, dan melaporkan semua transaksi keuangan, aset, hutang, dan ekuitas dari seluruh Pemerintah Pusat dan instansiinstansinya. SAPP terdiri dari dua subsistem utama, yaitu Sistem Akuntansi Pusat (SAP) dan Sistem Akuntansi Instansi (SAI). Tanggung jawab SAI diserahkan kepada Kepala Departemen/Lembaga dalam hal ini Menteri/Ketua dibantu oleh unit akuntansi di bawah Sekretaris Jenderal sedangkan tanggung jawab SAP diserahkan kepada Menteri Keuangan yang dibantu oleh Badan Akuntansi Keuangan Negara (BAKUN).

Setiap subsistem utama dibagi menjadi beberapa subsistem yang dirancang untuk memenuhi kebutuhan akuntansi dan informasi dari pemakai tertentu. Subsistem dalam SAP dan SAI didesentralisasikan di propinsipropinsi. Masing-masing subsistem akan memenuhi tujuan-tujuan informasi akuntansi dan pengawasan dari setiap instansi atau bagian dari Pemerintah Pusat. Secara keseluruhan sistem akuntansi ini akan memberikan kepada Dewan Perwakilan Rakyat, para pengambil keputusan tingkat tinggi pemerintah, dan pihak yang berkepentingan lainnya informasi yang mencukupi, relevan, dan tepat waktu mengenai realisasianggaran serta posisi keuangan dari seluruh Pemerintah Pusat atau dari masing-masing instansi.

Input SAPP adalah berupa dokumen sumber transaksi keuangan pemerintah seperti SPM (Surat Perintah Membayar), SSP 
(Surat Setoran Pajak), SSBP (Surat Setoran Bukan Pajak), SSBC (Surat Setoran Bea Cukai), arsip data komputer aset tetap, arsip data komputer transaksi interegional dan lain-lain sedangkan output yang dihasilkan oleh SAPP adalah laporan keuangan tingkat proyek, laporan realisasi anggaran pendapatan, neraca anggaran rutin, dan Perhitungan Anggaran Negara. Pemrosesan input untuk SAPP dilakukan oleh Kantor Akuntansi Regional (KAR) yang terdapat di berbagai daerah di lndonesia. KAR adalah instansi vertikal BAKUN yang berada di bawah dan bertanggung jawab langsung kepada Kepala BAKUN. Dalam menyelenggarakan tugasnya KAR berfungsi sebagai pengumpulan dan verifikasi dokumen transaksi keuangan pemerintah, pengolahan data transaksi keuangan pemerintah, pendistribusian hasil pengolahan data akuntansi, pelaksanaan sistem akuntansi pusat, analisis laporan keuangan pemerintah, bimbingan teknis SAP termasuk Sistem Akuntansi Aset Tetap kepada unit-unit akuntansi diwilayah kerjanya, dan pelaksanaan administrasi KAR.

Pada suatu sistem akuntansi, laporan keuangan yang dihasilkan sangat bergantung pada keakuratan dan keabsahan input data transaksinya. Berdasarkan fungsi tersebut di atas berarti bahwa input SAPP dari setiap transaksi keuangan pemerintah berada di bawah tanggung jawab KAR. Ini berarti bahwa tugas yang diemban oleh KAR sangat penting. Keakuratan dan keabsahan laporan keuangan pemerintah yang dihasilkan tergantung dari kualitas kerja yang dilakukan oleh KAR dalam mengelola input data transaksi keuangan pemerintah. Akan tetap seringkali muncul kendal-kendala/masalahmasalah dalam pengolahan input sehingga output yang dihasilkan tidak sesuai dengan keadaan yang sebenamya dan tidak akurat. Padahal hasil yang akurat hanya dapat dicapai jika input yang dimasukkan juga akurat.

\section{Rumusan Masalah}

Penelitian ini dilakukan untuk menganalisis beberapa permasalahan terkait penggunaan Sistem Akuntansi Pusat oleh KAR Jakarta berikut ini, yaitu:

1. Seperti apakah proses yang terjadi pada KAR Jakarta?

2. Apakah masalah-masalah/kendala-kendala yang dihadapi oleh KAR dalam mengelola data transaksikeuangan pemerintah?

3. Bagaimana mengatasi masalahmasalah/kendala-kendala yang dihadapi oleh KAR dalam mengelola data transaksi keuangan pemerintah?

\section{Tujuan Penelitian}

Tujuan dari penelitian ini adalah:

1. Memberikan gambaran yang jelas dan sebenamya tentang proses yang terjadi pada KAR Jakarta.

2. Memberikan gambaran yang jelas dan sebenarnya tentang masalahmasalah/kendala-kendala yang dihadapi oleh KAR dalam mengelola data transaksi keuangan pemerintah

3. Melakukan analisis dan pembahasan terhadap masalah-masalah/kendala- 
kendala yang dihadapi oleh KAR Jakarta sehingga dapat memperoleh solusi untuk mengatasi masalah tersebut.

\section{Metode Penelitian}

Metode penelitian yang digunakan dalam penelitian ini adalah dengan menganalisis masalah/kendala yang dihadapi oleh KAR Jakarta dan proses yang saat ini dilaksanakan oleh KAR Jakarta. Metoda dan teknik yang digunakan dalam analisis adalah dengan Critical Succes Factor (CSF) bagi KAR Jakarta, Data Flow Diagram (DFD), Entity Relatonship Diagram (ERD), dan Network Modeling. Selanjutnya berdasarkan teori-teori yang didapat daristudi literatur akan dicari pemecahannya.

\section{ANALISIS DAN PEMBAHASAN}

\section{ANALISIS}

\section{a. Gambaran Umum Sistem Akuntansi pada KAR Jakarta}

Sistem Akuntansi Pemerintah Pusat terdiri dari subsistem-subsistem: pengeluaran (Cash Disbursement/CD), penerimaan (Cash Receip/CR), anggaran (Budgeting), aset tetap (Fixed Asset/FA), inveslasi permanen (Permanent lnvestment/PI), dan hutang jangkapanjang (Long-term Liabilities/LTL). Pada prakteknya, subsistem-subsistem tersebut dikerjakan oleh berbagai instansi. Berikut ini disajikan tabel yang menjelaskan tentang instansi dan subsistem yang digunakan oleh instansi tersebut.

Tabel 1.1

Instansi dan Subsistem yang Digunakan

\begin{tabular}{|c|c|c|c|}
\hline No. & Subsistem & $\begin{array}{l}\text { Pengolahan Data } \\
\text { Dilakukan oleh }\end{array}$ & Keterangan \\
\hline 1. & $\mathrm{CD}$ & KAR,KAK & $\begin{array}{l}\text { - KAR hanya mengolah data pengeluaran kas } \\
\text { negara yang dilakukan oleh KPKN. } \\
\text { - KAK hanya mengolah data pengeluaran kas } \\
\text { negara yang dilakukan DJA Pusat. }\end{array}$ \\
\hline 2. & $\mathrm{CR}$ & KAK, KAR & $\begin{array}{l}\text { - KAR hanya mengolah data penerimaan kas } \\
\text { negara yang dilakukan oleh KPKN. } \\
\text { - KAK hanya mengolah data penerimaan kas } \\
\text { negara yang dilakukan DJA Pusat. }\end{array}$ \\
\hline 3. & Budgeting & KAK & \\
\hline 4. & GL & KAK, KAR & \\
\hline 5. & FA & $\begin{array}{l}\text { Instansi } \\
\text { (Kantor/Proyek) }\end{array}$ & \\
\hline 6. & PI & KAK & $\begin{array}{l}\text { Yang melaporkan datanya adalah penanggung } \\
\text { jawab investasi. }\end{array}$ \\
\hline 7. & LTL & KAK & $\begin{array}{l}\text { Yang melaporkan datanya adalah penanggung } \\
\text { jawab hutang. }\end{array}$ \\
\hline
\end{tabular}




\section{Subsistem-subsistem yang Digunakan oleh}

\section{KAR Jakarta}

Dari tabel di atas terlihat bahwa sistem Kantor Akuntansi Regional Jakarta menggunakan subsistem-subsistem berikut ini untuk menjalankan fungsinya:

\section{- Subsistem cash disbursement (pengeluaran)}

Subsistem ini digunakan untuk mengolah semua dokumen sumber pengeluaran pemerintah yang diterima Kantor Akuntansi Regional dari Kantor Tata Usaha Anggaran (KTUA).Dokumen sumber tersebut adalah dalam bentuk SPM (Surat Perintah Membayar). Adabanyak jenis format SPM, yaitu: (a) format untuk rutin, pembangunan, UYHD rutin, UYHD pembangunan, PFK yang tidakdianggarkan, (b) Format untuk SPM U PEMDA, (c) Format untuk pendapatan yang dibayarkan kembali.

Cash disbursement termasuk cash transfer-out dan dokumen WP yang telah dibayar.SPM dapat dikelompokkan secara logik ke dalam berikut ini: (a) Pengeluaran rutin, (b) Pengeluaran pembangunan, termasuk transaksi-transaksi $\quad$ BA16 berdasarkan allotmenDIP, (c) UYHD rutin, pembayarannya melalui kas yang dibayar dimuka, (d) PFK yang tidak dianggarkan termasuk SPM U PEMDA, (e) Pembayaran kembali pendapatan, termasuk pembayaran pajak, pembayaran bea dancukai dan pembayaran pendapatan lainnya, (f) transfer kas keluar (g) WP yang telah dibayarkan.

Selain dokumen sumber pengeluaran KTUA juga memberikan fileinterface arsip datakomputer (ADK) dan print out rekapitulasi P7 yang biasanya dibuat per Bagian Anggaran.Dokumen sumber tersebut diterima, diteliti dan dibukukan oleh sub bagian umum KAR.Dokumen sumber akan diberikan ke seksi verifikasi untuk dibatch dan dibandingkan dengan Register Transaksi Harian (RTH) yang dicetak oleh Seksi pengolahan Data Akuntansi(SPDA).Sedangkan fileinterface (ADK) diberikan kepada SPDA. SPDA mencetak RTHyang kemudian dikirim ke seksiverifikasi, dan membentuk GL entries pengeluaran.

\section{- Subsistem cash receipt (penerimaan)}

Subsistem ini digunakan untuk mengolah semua dokumen sumber penerimaan pemerintah yang diterima Kantor Akuntansi Regional dari Kantor Tata Usaha Anggaran (KTUA). Dokumen tersebut berbentuk SSP untuk pendapatan dari penerimaan pajak, VAT receipt, rentaltax receipt, dan penerimaan pajak lainnya.

a) SSBC untuk pendapatan bea dan cukai

b) SSBP untuk pendapatan bukan pajak, seperti pendapatan dari minyak, pendapatan sewa, pendapatan dari penjualan, dan pendapatan lainnya.

c) SSBP UYHD untuk UYHD Rutin dan UYHD Pembangunan.

d) KU-ln untuk transfer kas.

Berdasarkan informasi dari dokumen sumber di atas, untuk semua dokumen kecuali KU-In akan disusun dan dibatch menurut urutan berikut ini: (a) Wilayah KPKN, (b) Bagian Anggaran dan Eselon I, (c) KodeBKPP, (d) Kode KPKN. 
Untuk KU-In, dokumen akan dibatch menurut urutan Kode KPKN, Kode BKPP, Tanggal dokumen dari transaksi asal.

Selain dokumen sumber penerimaan KTUA juga memberikan fileinterface arsip data komputer (ADK) dan print out rekapitulasi P7 yang biasanya dibuat per Bagian Anggaran. Dokumen sumber tersebut diterima, diteliti dan dibukukan oleh sub bagian umum KAR. Dokumen sumber akan diberikan ke seksi verifikasi untuk dibatch dan dibandingkan dengan Register Transaksi Harian (RTH) yang dicetak oleh Seksi pengolahan Data Akuntansi (SPDA). Sedangkan fileinterface (ADK) diberikan kepada SPDA. SPDA mencetak RTH yang kemudian dikirim ke seksi verifikasi, dan membentuk GL entries penerimaan.

\section{- Subsistem general ledger (buku besar)}

Pada subsistem ini semua GL entries yang dihasilkan oleh subsistem pengeluaran maupun penerimaan akan diposting ke buku besar sehingga membentuk GL detail. Dari GL detail akan dicetak daftar transaksi dan posting (DT\&P). GL detail dan DT\&P ini kemudian dikirim oleh KAR ke instansiinstansi Kantor Pusat BAKUN, Unit Akuntansi Wilayah (UAW), dan Unit Akuntansi Eselon (UAE). Jika terjadi kesalahan misalnya ada data yang belum terekam atau data yang salah maka UAW akan membuatkan memo penyesuaian (MP) untuk kesalahan tersebut dan mengirimkan MP tersebut ke KAR. Oleh KAR MP tersebut dibagikan ke seksi verifikasi untuk dibatch dan ke SPDA. SPDA kemudian akan membetulkan kesalahan yang terjadi berdasarkan MP yang diterima. SPDA akan mencetak RTH MP untuk diperiksa oleh seksi verifikasi. Jika masih ada yang salah maka seksi verifikasi akan memberikan tanda pada RTH untuk diperbaiki oleh SPDA. Setelah RTH dinyatakan benar maka akan dilakukan posting transaksi MP ke buku besar.

Subsistem - subsistem tersebut dikerjakan oleh Kantor Akuntansi Regional Jakarta melalui 4 bagian yang dimilikinya, yaitu sub bagian umum, seksi verifikasi, Seksi Pengolahan Data Akuntansi (SPDA), dan seksi Konsolidasi. Adapun tugas dan urutan kerja yang dilakukan oleh bagian tersebut adalah:

Sub Bagian Umum:

a) Menerima arsip data komputer (ADK) interface dan dokumen sumber (DS) dariKTUA.

b) Membukukan penerimaan.

c) Menyerahkan ADK ke seksi PDA dan DS ke seksiverifikasi.

Seksi Verifikasi:

a) Menerima DS dari sub bagian umum.

b) Membagikan DS ke pelaksana.

c) Menerima dan membagikan Register Transaksi Harian (RTH).

d) Mencocokkan RTH dengan DS.

e) Mencocokkan RTH perbaikan.

f) Meminta pembentukan GL entries.

g) Menerima dan membagikan data transaksi dan posting (DT\&P).

h) Membuat pengantar ADK dan DT\&P ke instansi. 
i) Mengirim ke instansi.

\section{Seksi PDA:}

a) Menerima ADK darisub bagian umum.

b) Konversi data

c) Interface data.

d) Mencetak RTH

e) Mengirim RTH ke verifikasi.

f) Memperbaiki RTH.

g) Mengirim RTH perbaikan.

h) Menerima permintaan pembentukan GL entries.

i) Menyetujui pembentukan GLentries.

j) Membentuk GL entries.

k) Mengirim GL entries ITR (interegional) ke KAK.

1) Menerima GL entries ITR dari KAK.

m) Melakukan posting.

n) Mencetak DT\&P.

o) Mengirim DT\&P ke verifikasi.

p) Mencetak register pengiriman GL detail untuk KP BAKUN, UAW dan UAE.

q) Download ke ADK KP BAKUN, UAW, dan UAE.

Apabila ada estimasi pendapatan, saldo awal harus diinput. Setelah itu urutan kerja sama dengan dari poin $d$ sampai j. Sebelumnya tabel saldo sudah diterima dari KAK bersama dengan allotmentnya.

\section{Seksi Konsolidasi:}

Membuat laponan gabungan dari semua transaksi yang terjadi. Laporan konsolidasi dapat berupa laporan gabungan transaksi dari bulan ke bulan atau dari tahun ke tahun.

Menurut BAKUN (1999) SAPP adalah suatu sistem terpadu yang menggabungkan prosedur manual dan proses elektronis untuk mengambil data, mernbukukan, dan melaporkan atas semua transaksi keuangan, aset, hutang, dan ekuitas dari seluruh pemerintah pusat dan instansi-instansinya. SAPP terdiri dari dua subsistem utama, yaitu Sistem Akuntansi Pusat (SAP) dan Sistem Akuntansi lnstansi (SAI. Tanggung jawab SAI diserahkan kepada Kepala Departemen/Lembaga dalam hal ini Menteri/Ketua dibantu oleh unit akuntansidi bawah Sekretaris Jenderal sedangkan tanggung jawab SAP diserahkan kepada Menteri Keuangan yang dibantu oleh Badan Akuntansi Keuangan Negara (BAKUN). SAP mempunyai dua subsistem akuntansi dan pelaporan keuangan yang akan dilaksanakan oleh BAKUN melalui Kantor Akuntansi Regional (KAR) didaerah dan Kantor Pusat BAKUN di Jakarta, yaitu Sistem Akuntansi Umum (SAU) dan Sistem Akuntansi Kas Umum Negara (SAKUN). SAU membukukan dan melaporkan secara sentral mengenai AnggaranPendapatan dan Belanja Negara (APBN), alotment dan estimasi pendapatan,pendapatan dan belanja yang direalisasi, aset lancar, aset permanen, aset tetap, asetlain-lain, hutang jangka pendek, dan hutang jangka panjang, saldo dana lancar (surplus atau defisit), dan ekuitas dana yang diinveslasikan yang berasal dari transaksi instansi-instansiPemerintah Pusat. Sedangkan SAKUN meliputi perkiraan-perkiraan dana/kas pusat yang dipelihara oleh unitunitdibawah Direktorat Jenderal Anggaran (DJA), khususnya Kantor Perbendaharaan danKas Negara (KPKN), Direktorat Tata 
Usaha Anggaran (DTUA), dan Direktorat Perbendaharaan dan Kas Negara (DPKN). Dari penjelasan tersebut dapat dilihat kaitan antara Sistem KAR, SAP, dan SAI.

\section{Kaitan Antara Sistem KAR, SAP, dan SAI}

Proses SAPP di BAKUN oleh KAR dan KAK. Pada KAR dokumen sumbemya berasal dari:

a) DJA KTUA (Direktorat Jenderal Anggaran Kantor Tata Usaha Anggaran), berupa dokumen sumber pengeluaran kas/penerimaan kas \&fileinterface.

b) DJA KPKN (Direktorat Jenderal Anggaran Kantor Perbendaharaan \& Kas Negara),berupa DIP dan SPMU PEMDA.

c) DJA KANWIL (Direktorat Jenderal Anggaran Kantor Wlayah), berupa altotment (kredit anggaran) wilayah/revisi estimasi pendapatan.

d) Unit Akuntansi UAW Eselon I, berupa memo penyesuaian/koreksi e) PPBI (Pembantu Penguasa Barang lnventaris) yang merupakan instansis etingkat kantor wilayah, berupa arsip data komputer aset tetap.

f) KAK (Kantor Akuntansi Khusus) berupa tabel master, arsip data komputer buku besardetail KAR Khusus dan arsip data komputerinteregional.

Pada KAK dokumen sumbernya berasal dari DJA DTUA dan DJA KPKN yang diolah dan menghasilkan tabel master, arsip data komputer buku besar detail KAR Khusus dan arsip data komputer interegional. Hasil-hasil inilah yang dikirim ke KAR.

Semua dokumen sumber tersebut masuk ke KAR dan diproses. Hasil dari proses tersebut adalah GL detail yang dipisahpisahkan menurut instansi (arsip data buku besar).GL yang telah dipisah-pisahkan ini kemudian dikirim oleh UAW ke UAEI dan dari UAEI dikirim ke UAKPI.

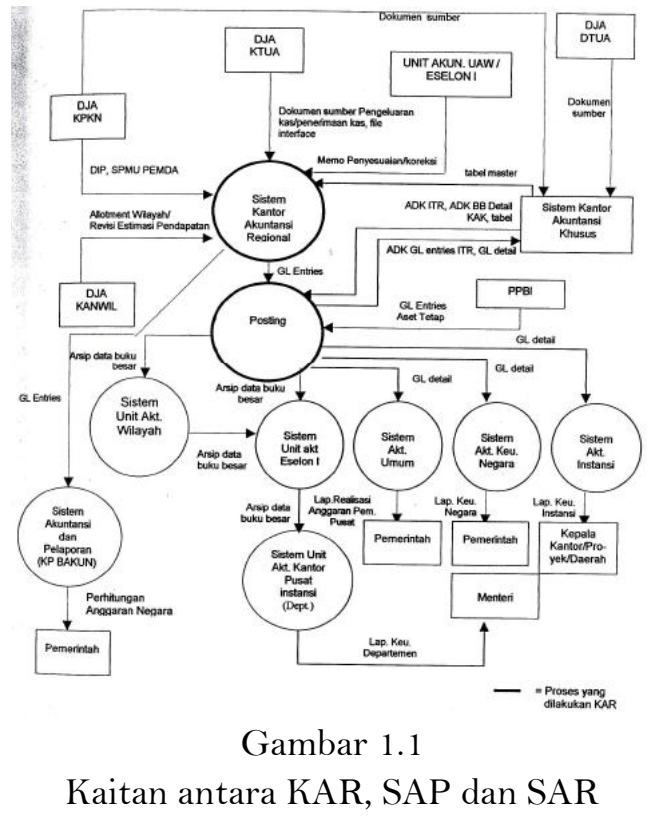


SAU, SAKUN, dan SAI memperoleh arsip buku besar detail dari KAR. Kemudian setiap sistem berdasarkan arsip data buku besar detail yang diperoleh dari KAR akan diolah untuk menghasilkan laporan keuangan yang akan diberikan kepada:

- Laporan keuangan dari SAU akan diberikan kepada pemerintah.

- Laporan keuangan dari SAKUN akan diberikan kepada pemerintah.

- Laporan keuangan dariSAl akan diberikan kepada Kepala Kantor/proyek/Daerah

Sementara itu di UAKPI data diproses untuk menghasilkan laporan RealisasiAnggaran tingkat kantor maupun tingkat proyek dan neraca percobaan untuk setiapdepartemen per wilayah. Laporanlaporan ini kemudian diverifikasi terhadap dokumensumbernya.

Seharusnya jika diperiksa, laporan yang dihasilkan oleh UAKPI akan memiliki jumlahyang sama dengan laporan PAN (Perhitungan Anggaran Negara) yang dihasitkan oleh KP BAKUN. Akan tetapikarena fasilitas yang ada diUAKPI kurang memadaimaka laporan yangdihasilkan menjadi tidak sama.

\section{b. Masalah dan atau Kendala-kendala yang Dihadapi oleh KAR Jakarta}

Masalah atau kendala-kendala yang dihadapi oleh KAR Jakarta antara lain:

\section{Kelengkapan dokumen sumber.}

Dokumen sumber banyak yang tidak lengkap sehingga tidak diketahui secara pasti berapa jumlah SPM (Surat Perintah Membayar), SSP (Surat Setoran pajak), SSBP (surat setoran Bukan pajak), dan SSBC (surat setoran Bea dan cukai).

Ketidaklengkapan tersebut dapat berupa:

- Arsip Data Komputer (ADK, berupa disket dari I(TUA) ada tetapi dokumen sumbemya (DS) belum ada.

- Arsip Data Komputer ada, dokumen sumber ada tetapi tidak lengkap.

- Arsip Data Komputer tidak ada tetapi dokumen sumber ada.

Untuk mengatasi hal tersebut beberapa langkah yang telah ditempuh oleh KAR adalah:

- Jika arsip data komputer ada tetapi dokumen sumbernya belum ada biasanya dipecahkan berdasarkan pengalaman sebelumnya jika menghadapi hal yang sama.

- Jika arsip data komputer ada, dokumen sumber ada tetapi tidak lengkap biasanya dipecahkan dengan : SPM yang ada dianggap benar, dihitung, kemudian dicocokkan dengan rekapitulasi PT kemudian dibandingkan dengan RTH. RTH dibandingkan/diperiksa lagi berdasarkan dokumen pendukungnya seperti Daftar lsian Kegiatan dan Dafrar 1sian Proyek. Rekapilulasi P7 dibuat dari ADK yang diterima kemudian dibuat rekapitulasinya berdasarkan kode BA (Bagian Anggaran). Atau dipecahkan berdasarkan pengalaman sebelumnya jika menghadapi hal yang sama. 
- Jika arsip data komputer tidak ada tetapi dokumen sumber ada maka staf SPDA di KAR harus menginput data berdasarkan dokumen sumber yang diterima. Dokumen sumber biasanya terdiri dari dua unsur, yaitu:

○ Fisik berupa disket yang berisi arsip data komputer.

○ Elemen data. Misalnya elemen data untuk SPM adalah:

- kegiatan lain (Daftar lsian

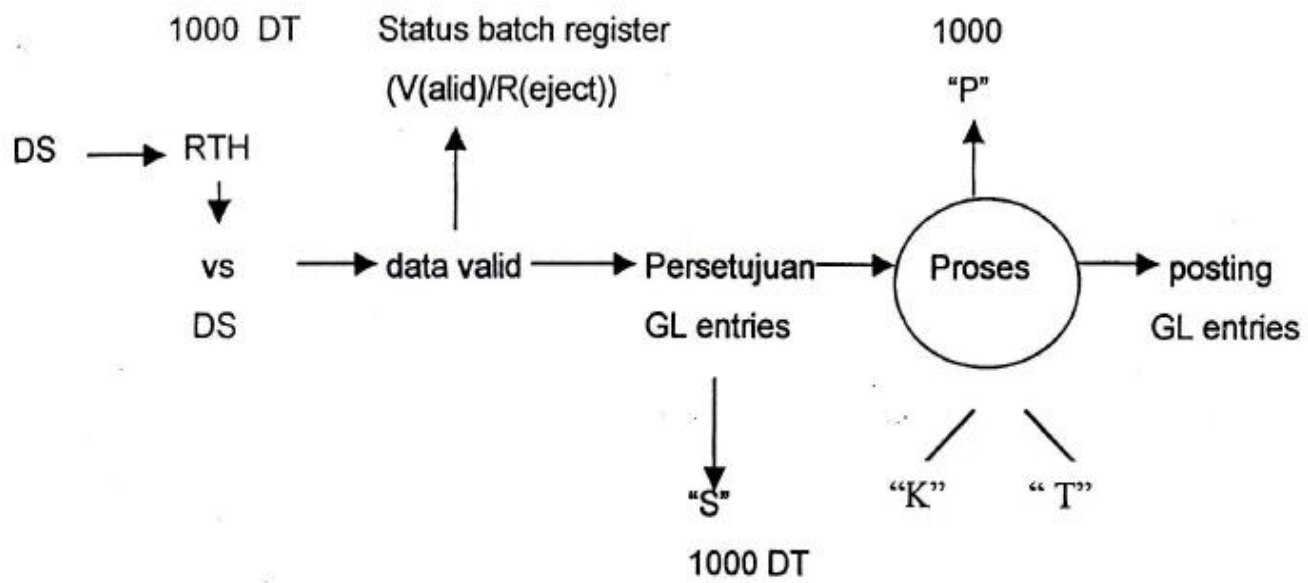

DT= data transaksi

Gambar 1.2

Urutan Kerja SeksiVerifikasi

RTH (Register Transaksi Harian) yang telah dicetak oleh SPDA akan diperiksa oleh seksi verifikasi. RTH dibandingkan dengan dokumen sumber yang ada (misalnya ada 1000 transaksi). Setelah RTH dibandingkan dengan dokumen sumber dan data dinyatakan valid (benar) maka status batch register akan menunjukkan huruf "V" yang berarti benar ada 1000 transaksi. Pada saat GL entries terbentuk dan statusnya adalah "S" (setuju) maka itu berarti bahwa transaksi yang terbentuk pada GL entries juga 1000
Kegiatan/Dafiar lsian proyek)

- Sektor Subsektor Program (SSP)

- MAK/MAP,

- BA-ES sepertiSKO dan DIK S

\section{Masalah verifikasi yang belum cermat}

Urutan prosesnya adalah sebagai berikut (pekerjaan ini dikerjakan oleh seksi verifikasi):

1000 DT 
UNIX dan bahasa pemrograman PowerHouse. ADK interface dari KTUA tensebut harus dikonversi dari file.DBF menjadi file.TXT terlebih dahulu agar dapat digunakan oleh sistem KAR Jakarta. Akan tetapi pada file hasil konversi masih terdapat data yang lolos atau tidak terproses sehingga tidak dapat dibuatkan rekapitulasi dari data penerimaan maupun pengeluaran pemerintah.Biasanya berdasarkan arsip data komputer yang masuk, KAR akan membuat rekapitulasi pengeluaran maupun penerimaan berdasarkan bagian anggaran.

\section{Elemen data SPM yang belum benar.}

Pada SPM terdapat informasi tentang kantor yang menerima dana serta kode bagian anggaran (kode departemen) dari kantor tersebut. Temyata terdapat ketidakcocokan data antara kantor yang menerima dana dan kode bagian anggarannya pada SPM yang dikeluarkan oleh KPKN. Sistem yang ada di KAR Jakarta saat ini belum memiliki mekanisme untuk mencek/memeriksa hal tersebut sehingga terjadi perbedaan pencatatan transaksi antara instansi/kantor

\section{PEMBAHASAN}

\section{a. Critical Success Factor bagi KAR Jakarta}

Tujuan KAR Jakarta adalah untuk menyediakan daftar transaksi dan posting (DT\&P) serta arsip data BB yang akurat dan benar bagi Kantor pusat BAKUN, UnitAkuntansi Wilayah (UAW), dan Unit Akuntansi Tingkat Eselon (UAE) untuk digunakan sebagai dasar pembuatan laporan keuangan laporan keuangan pemerintah, yang menerima dana dengan pencatatantransaksiyang dilakukan oleh KAR Jakarta.

\section{Kurangnya motivasi pegawai dalam menjalankan tugasnya.}

Jenis pekerjaan yang dilakukan oleh pegawai KAR Jakarta adalah jenis pekerjaan yang rutin dan membutuhkan ketelitian yang tinggi (antara lain seperti meneliti kelengkapan dokumen sumber, memeriksa data transaksi harian dan mencocokkannya dengan dokumen sumber) sehingga lamakelamaan akan menimbulkan kejenuhan para pegawai.Kondisi yang seperti ini ditambah dengan kurangnya ganjaran yang diberikan terhadap para pegawai membuat kurangnya motivasi para pegawai tersebut dalam menjalankan tugasnya. Akibatnya adalah hasil kerja yang dihasilkan oleh KAR Jakarta menjadi kurang optimal dan akurat. Padahal hasil kerja yang optimal dan akurat dibutuhkan karena output yang dihasilkan oleh sistem KAR Jakarta menjadi dasar bagi pembuatan laporan keuangan pemerintah.

laporan keuangan tingkat wilayah, laporan keuangan kantor/proyek, dan laporan keuangan tingkat eselon, laporan keuangan tingkat departemen/instansi.

Agar KAR Jakarta dapat mencapai tujuan tersebut maka Critical Success Factor (CSF) yang harus dimilikiadalah:

1. Dokumen sumber yang lengkap.

Pada sistem akuntansi, dasar dari pembuatan jumal adalah adanya dokumensumber yang merekam transaksi 
yang dilakukan. Tanpa adanya dokumen sumbermaka pembukuan yang dilakukan adalah tidak benar dan tidak akurat.

2. Pegawaiyang memilikimotivasi tinggi dalam menjalankan tugasnya.

Jenis pekerjaan yang dilakukan oleh pegawai KAR Jakarta adalah jenis pekerjaanyang rutin, membutuhkan ketelitian dan tidak bervariasi sehingga menimbutkankejenuhan para pegawainya. Sebagai instansi yang bertugas untuk menyediakan data dasar bagi pembuatan laporan keuangan pemerintah yang nantinya laporan tersebut digunakan untuk untuk perencanaan, penganggaran, pelaksanaan, penatausahaan, Pengendalian anggaran, perumusan kebijaksanaan, pengambilan keputusan, dan penilaian kinerja pemerintah maka KAR Jakarta harus memiliki pegawai yang memiliki motivasi yang tinggi dalam melaksanakan tugasnya sehingga data yang dihasilkan adalah data yang benar dan akurat.

3. Prosedur verifikasi yang baik

Agar data transaksi dan posting serta GL detail yang dihasilkan akurat maka KAR Jakarta harus prosedur verifikasi yang baik sehingga kesalahan sekecil apapun dapat ditemukan. Dengan demikian maka data yang dihasilkan menjadi akurat.

4. Infrastruktur yang memadai pada instansi terkait.

Sistem KAR berhubungan dengan instansi lain seperti KPKN, KTUA, UAW, UAE,DJA dan lain-lain. Lnstansiinstansi tersebut harus memiliki infrastruktur yang sesuai dengan kebutuhan dan dapat digunakan untuk mengolah data yang akan dikirim keKAR sehingga hasil kerja KAR Jakarta dapat selesai tepat pada waktunya karena hasil kerja KAR Jakarta diperlukan oleh instansi/lembaga lain untuk membantu dalam pengambilan keputusan, perencanaan, anggaran, penganggaran, pelaksanaan, penatausahaan, pengendalian anggaran, perumusan kebijaksanaan, pengambilan keputusan, dan penilaian kinerja pemerintah dan mempercepat penyajian Perhitungan Anggaran Negara (PAN) serta memudahkan pemeriksaan oleh aparat pengawasan fungsional secara efektif dan efisien.

5. Membuat sistem baru yang terpadu atau memperbaiki sistem yang sudah ada.

Hal ini perlu dilakukan agar dapat menghasilkan data yang benar, akurat, dan lebih cepat tersaji sehingga laporan yang dihasilkan juga menjadi laporan yang benar, akurat, dan tepat waktu.

\section{- Membuat sistem baru yang terpadu}

Seperti yang telah dijelaskan di atas bahwa sistem KAR berhubungan dengan instansi lain seperti KPKN, KTUA, UAW, UAE, DJA dan KP BAKUN sehingga akan lebih baik jika dibangun sistem baru yang terpadu. Terpadu berarti meliputi seluruh bagian yang terkait dan terintegrasilni diperlukan agar aliran data antar instansi yang berhubungan dapat berjalan dengan lebih lancar sehingga 
informasi yang dibutuh kan dapat segera dihasilkan.

- Memperbaiki sistem yang ada

Memperbaiki sistem yang ada berarti tetap mempertahankan sistem yang ada dan menambahkan beberapa prosedur yang sangat dibutuhkan serta memperbaiki beberapa prosedur yang kurang baik. Untuk sistem KAR Jakartabeberapa prosedur yang harus diperbaiki atau dibuatkan prosedur baru adalah:

$\checkmark$ Prosedur penerimaan dokumen
sumber.
Diperlukan prosedur perbaikan
untuk mengatasi ketidaklengkapan
dokumen sumber sehingga dapat
diketahui secara pasti berapa
pengeluaran dan pendapatan
pemerintah pada suatu waktu
tertentu.

$\checkmark$ Prosedur untuk verifikasi

Meskipun sudah dilakukan verifikasi dan pencocokan antara RTH dan dokumen sumber tetapi masih juga terdapat kesalahan pada RTH sehingga prosedur yang ada perlu diperbaiki agar data yang dihasilkan menjadi lebihakurat.

$\checkmark$ Prosedur input data dokumen sumber yang tidak disertai ADK.

Prosedur ini perlu dibuat agar data yang dihasilkan menjadi lebih akurat.

\begin{abstract}
$\checkmark$ Prosedur untuk mencek kesamaan antara kode kantor dan kode bagian anggaran pada SPM.

Prosedur ini perlu dibuat agar terdapat kesesuaian antara uang yang dikeluarkan oleh KPKN dan kegiatan yang dilakukan oleh instansi yangmenerima.

$\checkmark$ Membuat program konversi data yang tebih sempuma

Program konversi data yang lebih sempuma perlu dibuat mengingat KAR Jakarta menerima dokumen sumber dalam bentuk arsip data komputer dari sistem KTUA yang dibuat dengan bahasa pemrograman yang berbeda dengan bahasa pemrograman pada sistem KAR Jakarta. Dengan demikian maka proses konversi yang dilakukan akan sempuma (tidak ada data yang lolos).
\end{abstract}

\section{b. Evaluasi Perangkat Lunak Aplikasi Sistem Informasi}

Dari gambar 5 di bawah ini diketahui bahwa:

- Aplikasi GL data mempunyai nilai atau manfaat tertinggi bagi KAR Jakarta, disusul oleh aplikasiCD dan CR serta program konversidata.

- Aplikasi GL, CD, dan CR memiliki nilai bisnis dan teknis yang tinggi sehingga aplikasi tersebut harus dipelihara, ditingkatkan, dan dikembangkan lebih lanjut. 
- Program konversi data memiliki nilai bisnis yang tinggi namun nilai teknisnya rendah, maka aplikasiini harus diperbarui.

- Secara keseluruhan aplikasi sistem informasi yang ada mempunyai nilai teknis antara 4 dan 8 pada skala o sampai 10, yang berarti belum cukup memuaskan pemakai akhir dan perlu ditingkatkan serta disempumakan lebih lanjut

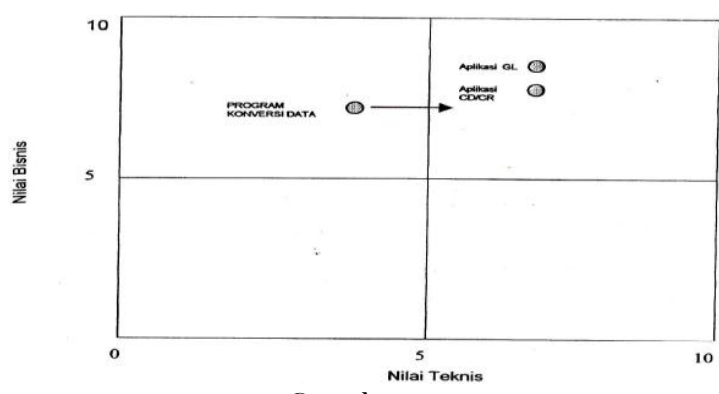

Gambar 1.3

Grid Evaluasi Perangkat Lunak

\section{$>$ Process Modeling}

Diagram konteks untuk Kantor Akuntansi Regional Jakarta adalah sebagaiberikut:

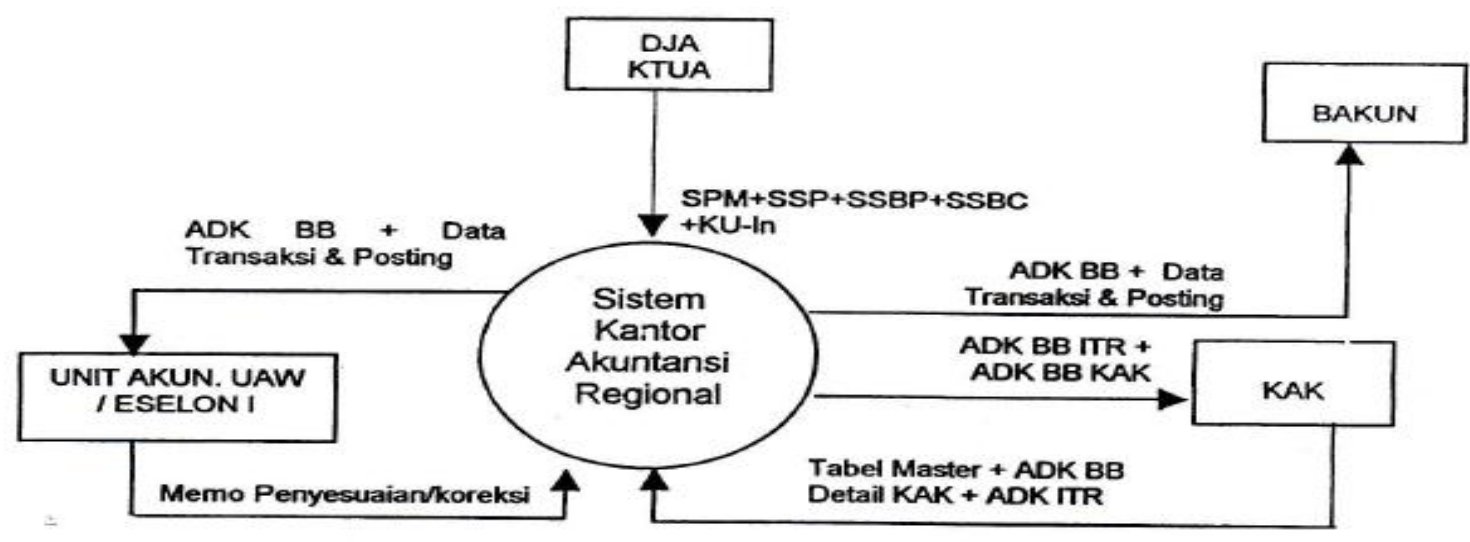

Gambar 1,4

Diagram Konteks KantorAkuntansi RegionalJakarta

Dari diagram diatas dapat diketahui bahwa Sistem Kantor Akuntansi Regional mendapat masukan dari :

- DJA KTUA (Direktorat Jenderal Anggaran Kantor Tata Usaha Anggaran), berupa dokumen sumber pengeluaran kas/penerimaan kas \&fileinterface.

- KAK (Kantor Akuntansi Khusus) berupa tabel master, arsip data komputer buku besar detail KAR Khusus dan arsip data komputer interregional.

- Unit Akuntansi UAWEselon l, berupa memo penyesuaian koreksi

Semua data tersebut diolah oleh KAR dan menghasilkan keluaran yang akan dikirim ke: 
- KAK, berupa arsip data komputer buku besar interegional dan arsip data komputer aset tetap.

- Unit akuntansi UAW/Eselon I, berupa arsip data komputer buku besar, daftar transaksi dan posting serta laporan lainnya.

- BAKUN, berupa arsip data komputer buku besar dan daftar transaksi dan posting.

\section{Functional Decomposition Diagram}

Sistem Kantor Akuntansi Regional Jakarta mengerjakan 3 subsistem dari SAPP, yaitu: subsistem Cash Disbursement (pengeluaran), subsistem Cash Receipt (penerimaan), dan subsistem General Ledger (buku besar). Functional Decomposition DiagramAkuntansi Regional adalah sebagai berikut.

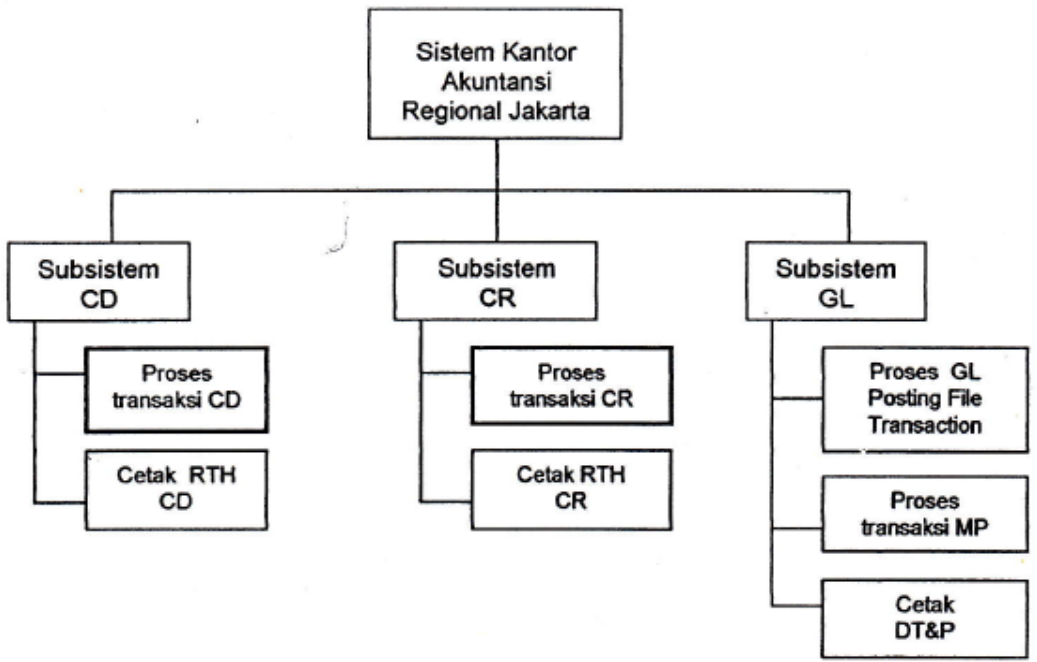

Gambar 1.5

Functional Decomposition Diagram

Sistem Kantor Akuntansi Regional Jakarta

\section{$>$ Event-Response List}

\section{Subsistem Cash Disbursement}

\begin{tabular}{|c|l|}
\hline No. & \multicolumn{1}{|c|}{ Event } \\
\hline 1 & $\begin{array}{l}\text { KAR menerima ADK interface / } \\
\text { dokumen sumber dari KTUA. }\end{array}$ \\
\hline 2 & $\begin{array}{l}\text { SPDA mengkonversi data (ADK) yang } \\
\text { diterima dari Sub bagian Umum. }\end{array}$ \\
\hline 3 & $\begin{array}{l}\text { Verifikasi mencocokkan DS } \\
\text { pengeluaran pemerintah Oengan RTH. }\end{array}$ \\
\hline 4 & SPDA memperbaiki RTH. \\
\hline 5 & Seksi verifikasi meminta pembentukan \\
\hline
\end{tabular}

GL entries kepada SPDA.

$\underline{\text { Subsistem Cash Receipt }}$

\begin{tabular}{|c|l|}
\hline No. & \multicolumn{1}{|c|}{ Event } \\
\hline 1 & $\begin{array}{l}\text { KAR menerima ADK interfacel } \\
\text { dokumen sumber penerimaan } \\
\text { pemerintah dari KTUA }\end{array}$ \\
\hline 2 & $\begin{array}{l}\text { SPDA rnengkonversi data (ADK) yang } \\
\text { diterima dari Sub Bagian Umum. }\end{array}$ \\
\hline 3 & $\begin{array}{l}\text { Seksi verifikasi rnencocokkan DS } \\
\text { pengeluaran pemerintah dengan RTH }\end{array}$ \\
\hline
\end{tabular}




\begin{tabular}{|c|l|}
\hline No. & \multicolumn{1}{|c|}{ Event } \\
\hline 4 & SPDA memperbaiki RTH. \\
\hline 5 & $\begin{array}{l}\text { Seksi verifikasi meminta pembentukan } \\
\text { GL entries kepada SPDA }\end{array}$ \\
\hline
\end{tabular}

$\underline{\text { Subsistem General Ledger }}$

\begin{tabular}{|c|l|}
\hline No. & \multicolumn{1}{|c|}{ Event } \\
\hline 1 & SPDA melakukan posting. \\
\hline 2 & SPDA mencetak DT\&P. \\
\hline 3 & $\begin{array}{l}\text { Seksi verifikasi membuat pengantar } \\
\text { ADK dan DT\&P untuk instansi. }\end{array}$ \\
\hline 4 & $\begin{array}{l}\text { Pencetakan register pengiriman GL } \\
\text { detail untuk KP BAKUN, UAW, dan } \\
\text { UAE oleh SPDA. }\end{array}$ \\
\hline 5 & $\begin{array}{l}\text { Ekspor file GL detail ke KP BAKUN, } \\
\text { KAK, UAW, dan UAE. }\end{array}$ \\
\hline 6 & $\begin{array}{l}\text { Memasukkan transaksi MP dari UAW } \\
\text { ke subsistem buku besar. }\end{array}$ \\
\hline 7 & Pemeriksaan RTH oleh seksi verifikasi. \\
\hline 8 & Pembentukan GL entries MP. \\
\hline 9 & Posting batch MP ke buku besar. \\
\hline
\end{tabular}

\section{E-R Modeling (Data Modeling)}

Sesuai dengan ruang lingkup dalam proses kegiatan KAR Jakarta, dapat diidentifikasi yang berikut ini:

\section{Jenis entity}

\begin{tabular}{|l|l|l|}
\hline - Organisasi & • Bukti & • Jenis \\
- SPM & Penerimaan & belanja \\
- Jenis SPM & Kas & - Cara \\
- Sifat SPM & - Payar \\
& • Cara Setor & • Bank \\
& • Perkiraan & • GL \\
& & Entries \\
& & • Jenis \\
& & perkiraan \\
\hline
\end{tabular}

\section{Jenis Relasi}

\begin{tabular}{|l|l|l|}
\hline Entity & Relasi & Entity \\
\hline Organisasi & Memiliki & $\begin{array}{l}\text { SPM } \\
\text { Bukti } \\
\text { penerimaan }\end{array}$ \\
\hline Perkiraan & Menerima & $\begin{array}{l}\text { SPM } \\
\text { Gl Entries }\end{array}$ \\
\hline Bank & Membayar & SPM \\
\hline P & Berada pada & $\begin{array}{l}\text { GL Entries } \\
\text { Organisasi }\end{array}$ \\
\hline Cara setor & Berada pada & $\begin{array}{l}\text { Bukti } \\
\text { penerimaan kas }\end{array}$ \\
\hline $\begin{array}{l}\text { Jenis } \\
\text { perkiraan }\end{array}$ & Berada pada & $\begin{array}{l}\text { Bukti } \\
\text { penerimaan kas }\end{array}$ \\
\hline Jenis belanja & Berada pada & SPM \\
\hline Cara bayar & Berada pada & SPM \\
\hline Jenis SPM & Berada pada & SPM \\
\hline Sifat SPM & Berada pada & SPM \\
\hline
\end{tabular}

\section{Cardinality}

\begin{tabular}{|c|c|}
\hline Entity/Relationship & Cardinality \\
\hline Organisasi dan SPM & $1: \mathrm{M}$ \\
\hline $\begin{array}{l}\text { Organisasi dan Bukti } \\
\text { penerimaan }\end{array}$ & $1: M$ \\
\hline Perkiraan dan SPM & $1: \mathrm{M}$ \\
\hline Perkiraan dan GL Entries & $1: \mathrm{M}$ \\
\hline $\begin{array}{l}\text { Perkiraan dan Bukti } \\
\text { penerimaan }\end{array}$ & $1: \mathrm{M}$ \\
\hline Banks dan SPM & $1: \mathrm{M}$ \\
\hline P dan GL Entries & $1: \mathrm{M}$ \\
\hline P dan Organisasi & $1: \mathrm{M}$ \\
\hline $\begin{array}{l}\text { Cara setor dan Bukti } \\
\text { penerimaan }\end{array}$ & $1: \mathrm{M}$ \\
\hline $\begin{array}{l}\text { Jenis perkiraan dan Bukti } \\
\text { penerimaan }\end{array}$ & $\begin{array}{l}1: M \\
1: M \\
\end{array}$ \\
\hline Jenis belanja dan SPM & $1: \mathrm{M}$ \\
\hline Cara bayar dan SPM & $1: \mathrm{M}$ \\
\hline Jenis SPM dan SPM & $1: \mathrm{M}$ \\
\hline Sifat SPM dan SPM & $1: \mathrm{M}$ \\
\hline
\end{tabular}

\section{Atribut dan Entity atau Relationship}

\begin{tabular}{|l|l|}
\hline \multicolumn{1}{|c|}{ Entity/Relationship } & \multicolumn{1}{|c|}{ Atribut } \\
\hline Organisasi & $\begin{array}{l}\text { Kode organisasi } \\
\text { Nama organisasi } \\
\text { Alamat organisasi } \\
\text { Kode wilayah }\end{array}$ \\
\hline Wilayah & $\begin{array}{l}\text { Kode wilayah } \\
\text { Deskripsi wilayah }\end{array}$ \\
\hline SPM & $\begin{array}{l}\text { No SPM } \\
\text { Tanggal SPM } \\
\text { Tahun Anggaran } \\
\text { Kode jenis belanja } \\
\text { Kode organisasi yang } \\
\text { mengeluarkan }\end{array}$ \\
\hline
\end{tabular}




\begin{tabular}{|l|l|}
\hline & Kode bank bayar \\
& No rekening \\
& Kode cara bayar \\
& Kode jenis SPM \\
& Kode sifat SPM \\
& Kode perkiraan \\
& Jumlah \\
& Penanggung jawab \\
\hline Perkiraan & Kode perkiraan \\
& Deskripsi perkiraan \\
\hline Bank & Kode bank \\
& Nama bank \\
\hline P & Kode P \\
& Deskripsi P \\
\hline Jenis belanja & Kode jenis belanja \\
& Deskripsi jenis belanja \\
\hline Cara bayar & Kode cara bayar \\
& Deskripsi cara bayar \\
\hline Jenis SPM & Kode jenis SPM \\
& Deskripsi jenis SPM \\
\hline Sifat SPM & Kode sifat SPM \\
& Deskripsi sifats SPM \\
\hline GL Entries & Kode organisasi \\
& Kode P \\
& Kode perkiraan \\
& Jumlah \\
& Tahun posting \\
& Bulan posting \\
& Tanggal posting \\
& Penanggung jawab \\
\hline Bukti pnerimaan kas & Kode organisasi \\
& Kode P \\
& Kode perkiraan \\
& Jumlah \\
& Tahun posting \\
& Bulan posting \\
& Tanggal posting \\
& Penanggung jawab \\
\hline & Kode cara setor \\
& Deskripsi cara setor \\
\hline & \\
\hline & \\
&
\end{tabular}

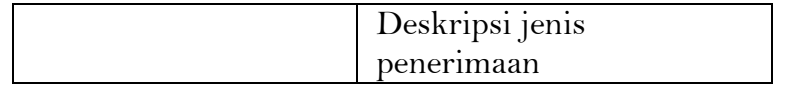

Atribut-atribut Primary Key dan Candidat Key

\begin{tabular}{|c|c|c|}
\hline Entity/Relationship & Primaru Key & $\begin{array}{c}\text { Alternate } \\
\text { Key }\end{array}$ \\
\hline Organisasi & $\begin{array}{l}\text { Kode } \\
\text { organisasi }\end{array}$ & \\
\hline Wilayah & Kode wilayah & \\
\hline SPM & No SPM & \\
\hline Perkiraan & $\begin{array}{l}\text { Kode } \\
\text { perkiraan }\end{array}$ & \\
\hline Bank & Kode bank & \\
\hline $\mathrm{P}$ & Kode P & \\
\hline Jenis belanja & $\begin{array}{l}\text { Kode jenis } \\
\text { belanja }\end{array}$ & \\
\hline Cara bayar & $\begin{array}{l}\text { Kode cara } \\
\text { bayar }\end{array}$ & \\
\hline Jenis SPM & $\begin{array}{l}\text { Kode jenis } \\
\text { SPM }\end{array}$ & \\
\hline Sifat SPM & $\begin{array}{l}\text { Kode sifat } \\
\text { SPM }\end{array}$ & \\
\hline GL Entries & $\begin{array}{l}\text { Kode } \\
\text { perkiraan }\end{array}$ & \\
\hline Bukti pnerimaan kas & $\begin{array}{l}\text { Kode } \\
\text { organisasi }\end{array}$ & \\
\hline Cara setor & $\begin{array}{l}\text { Kode cara } \\
\text { setor }\end{array}$ & \\
\hline Jenis penerimaan & $\begin{array}{l}\text { Kode jenis } \\
\text { penerimaan }\end{array}$ & \\
\hline
\end{tabular}

Berikut ini adalah gambar diagram ERD untuk sistem KAR Jakarta. 


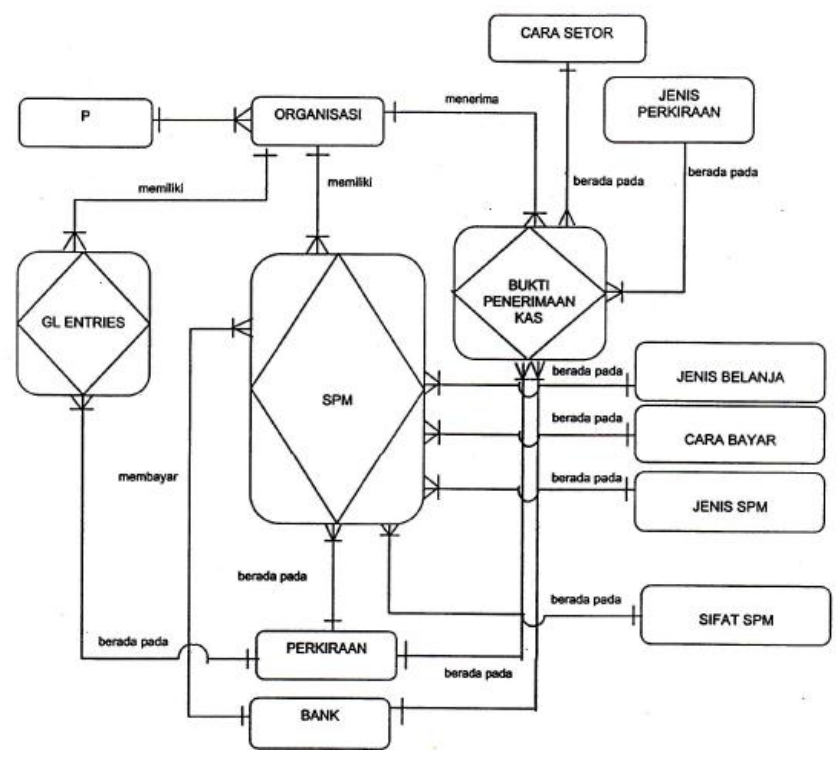

Gambar 1.6

ERD Sistem KAR Jakarta

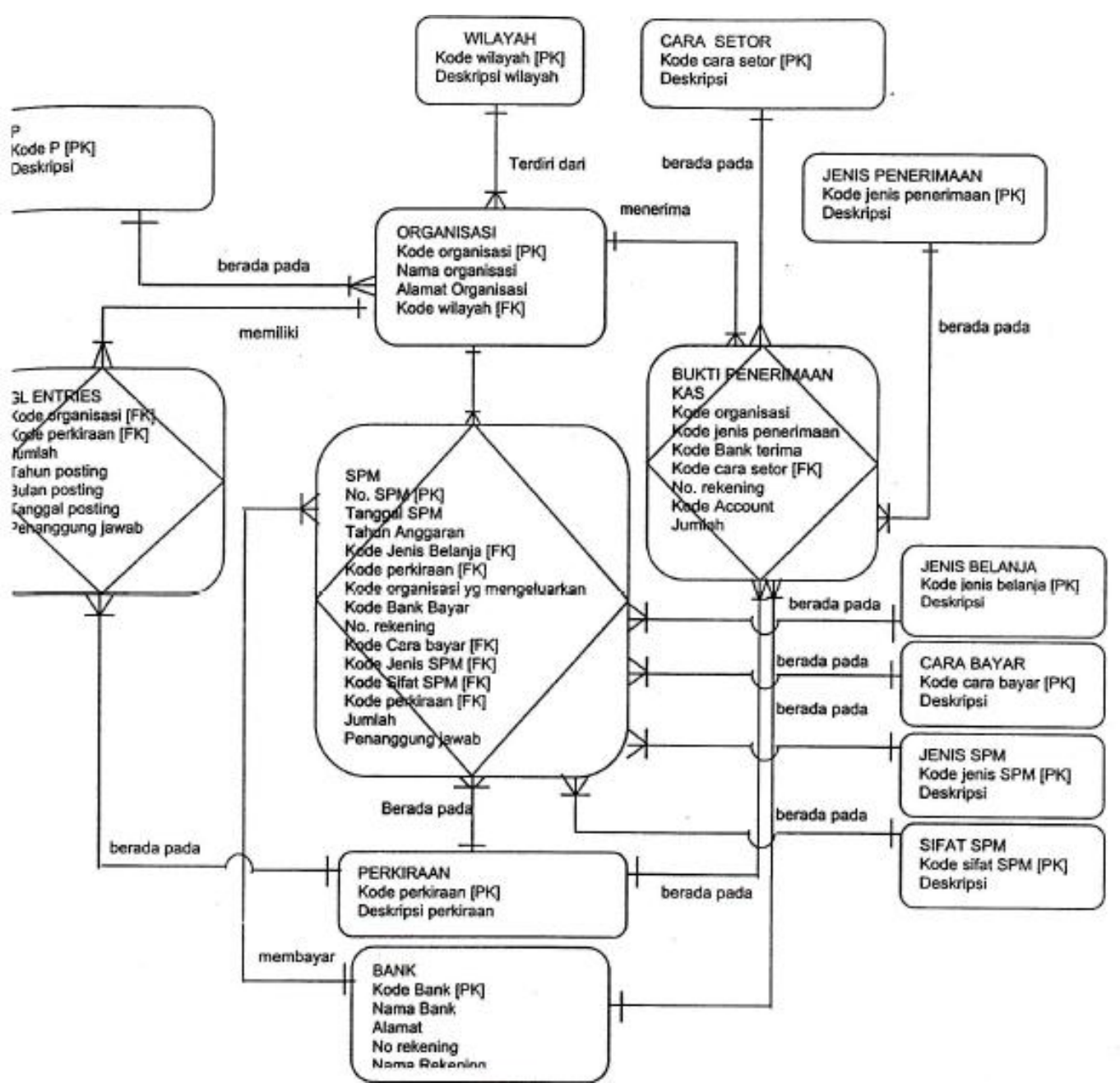

Gambar 1.7

A Fully Attributed ERD Sistem KAR Jakarta 


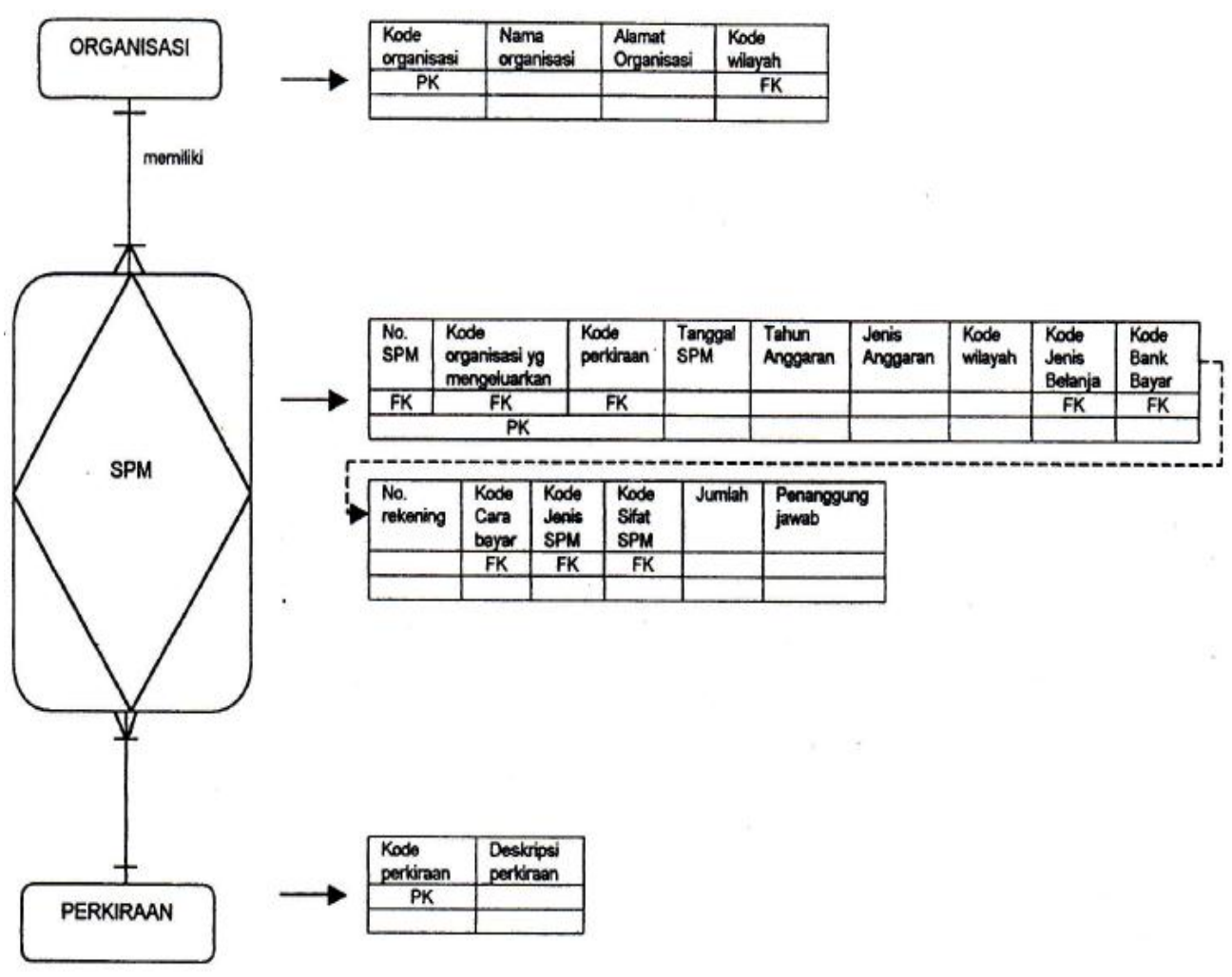

Gambar 1.8

Desain Tabel Organisasi, SPM, dan Perkiraan

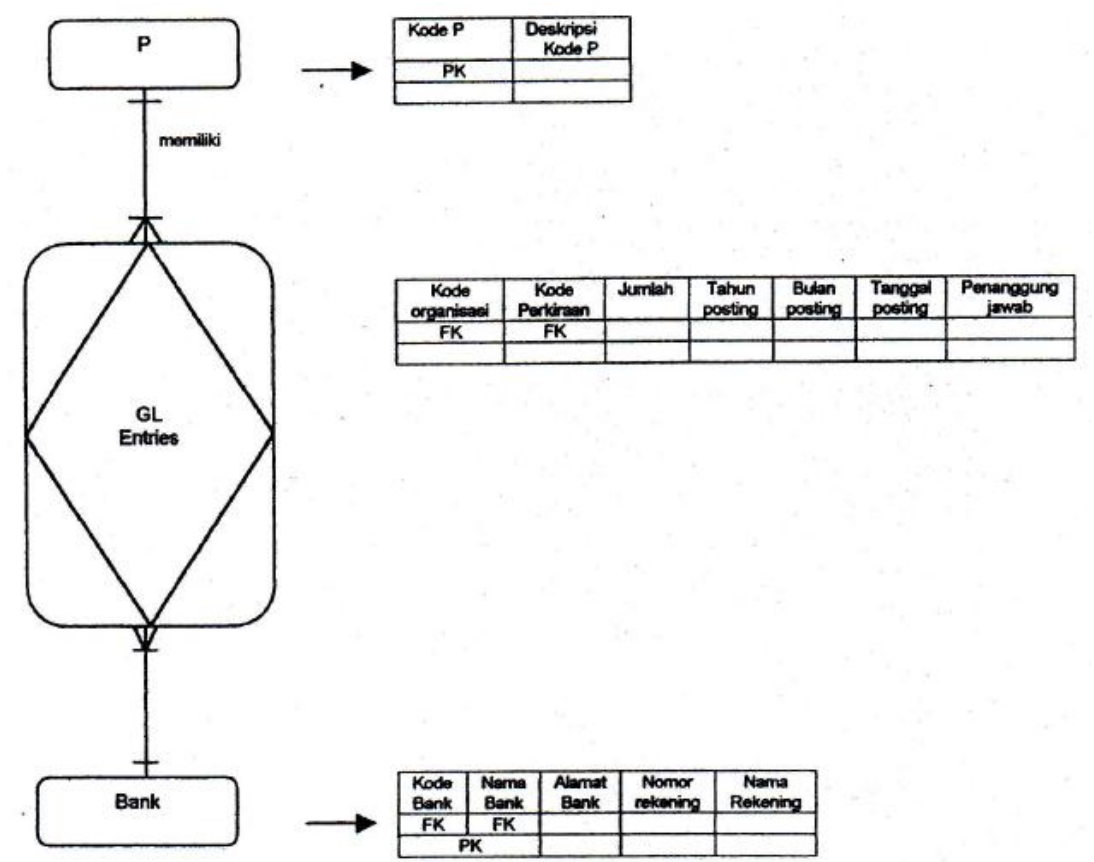

Gambar 1,9

Desain Tabel P, GL Entries, dan Bank 

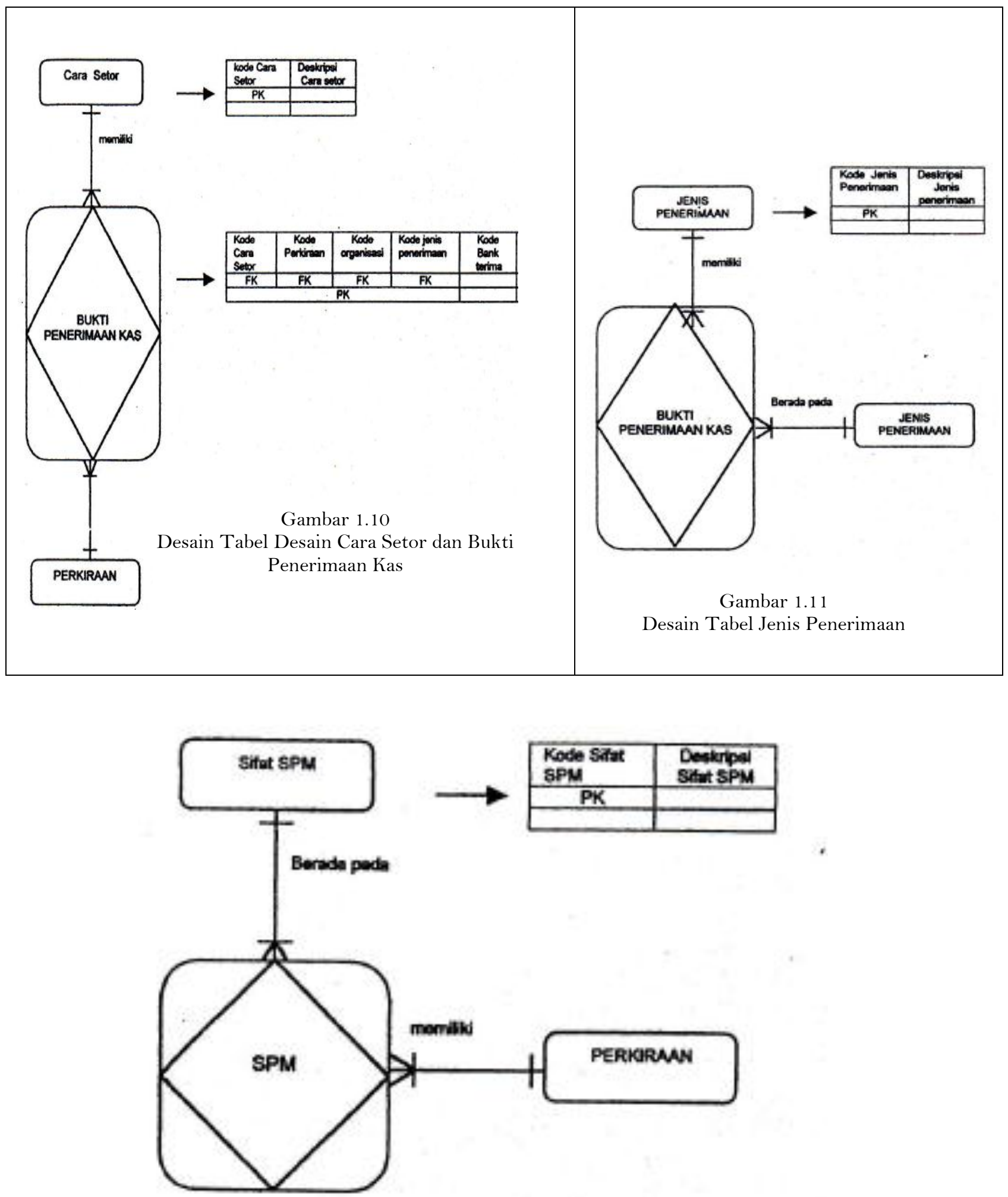

Gambar 1.12

Desain Tabel Sifat SPM 


\section{$>\quad$ Network Modeling}

Geografi dari Sistem berjalan pada Kantor Akuntansi Regional Jakarta adalah sebagai berikut:

\section{- Location Decomposition Diagram}

Sistem KAR Jakarta terdiri dari sub bagian umum, seksi verifikasi, seksi pengolahan data akuntansi, dan seksi konsolodasi. Masing-masing bagian terletak pada ruangan yang berbeda. Jika digambarkan dalam diagram lokasi akan menjadiseperti berikut ini.

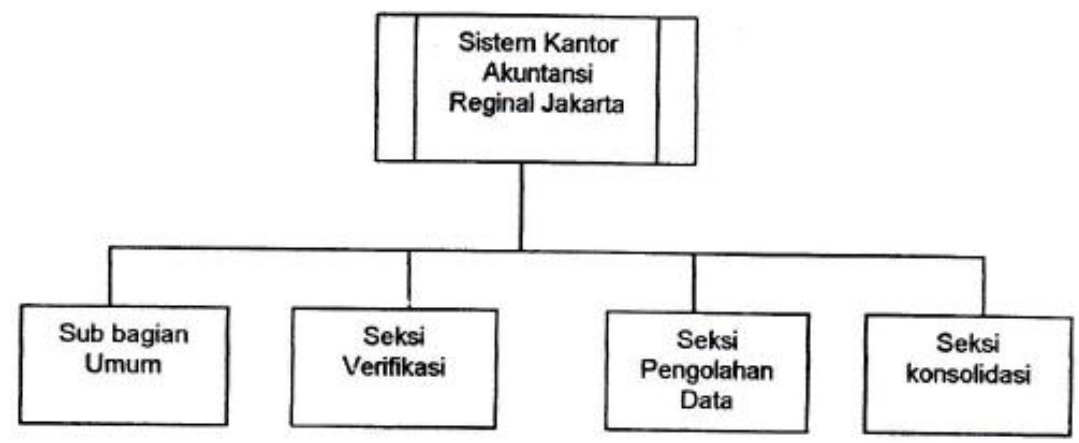

Gambar 1.13

Location Decomposition Diagram KAR Jakarta

Pada lokasi Sistem Kantor Akuntansi Regional Jakarta terdapat aplikasi Cash Disbursement (CD), Cash Receipt (CR), dan General Ledger (GL). Pelayanan yang diberikan oleh sistem ini adalah berupa daftar register transaksi harian, daftar transaksi dan posting serta menyediakan GL detail bagi UAW, UAE, KAK, dan BAKUN. Pada lokasi Sub bagian umum tidak terdapat aplikasi. Disini semua pekerjaan dilakukan secara manual. Pelayanan yang diberikan adalah penerimaan dokumen sumber penerimaan dan pengeluaran dan meneliti kelengkapan dokumen sumber tersebut. Pada lokasi seksi verifikasi tidak terdapat aplikasi. Disini semua pekerjaan dilakukan secara manual. Pelayanan yang diberikan adalah pemeriksaan terhadap register transaksi harian (RTH). Pada lokasi SPDA terdapat aplikasi CD, CR, dan GL. Pelayanan yang diberikan adalah menyediakan RTH bagi seksi verifikasi, data transaksi dan posting bagi UAW, UAE, KAK, dan BAKUN. Pada lokasi sesksi konsolidasi tidak terdapat aplikasi. Disini semua pekerjaan dilakukan secara manual. Pelayanan yang diberikan adalah menggabungkan semua SPM dari bulan ke bulan atau daritahun ke tahun.

- Location Conectivity Diagram

Setiap bagian dari Sistem KAR Jakarta saling berhubungan. Selain itu sistem KAR Jakarta juga berhubungan dengan sistem-sistem lain yang 
memberikan input data bagi sistem KAR Jakarta atau menerima output dari sistem KAR Jakarta. Sistem diluar KAR Jakarta tersebut adalah Sistem Unit Akuntansi Wilayah yang memberikan koreksi/memo pen-yesuaian atas DT\&P serta GL detail yang dihasilkan oleh sistem KAR Jakarta, sistem Kantor Tata usaha Anggaran yang memberikan dokumen sumber dan arsip data komputer pengeluaran/penerimaan pemerintah, sistem KantorAkuntansi Khusus yang memberikan tabel master, arsip data komputer buku besar dan arsip data komputer intenegional Kantor Akuntansi Khusus, dan sislem Unit Akuntansi Eselon I yang menerima DT\&P dan GL detail dari sistem KAR Jakarta.

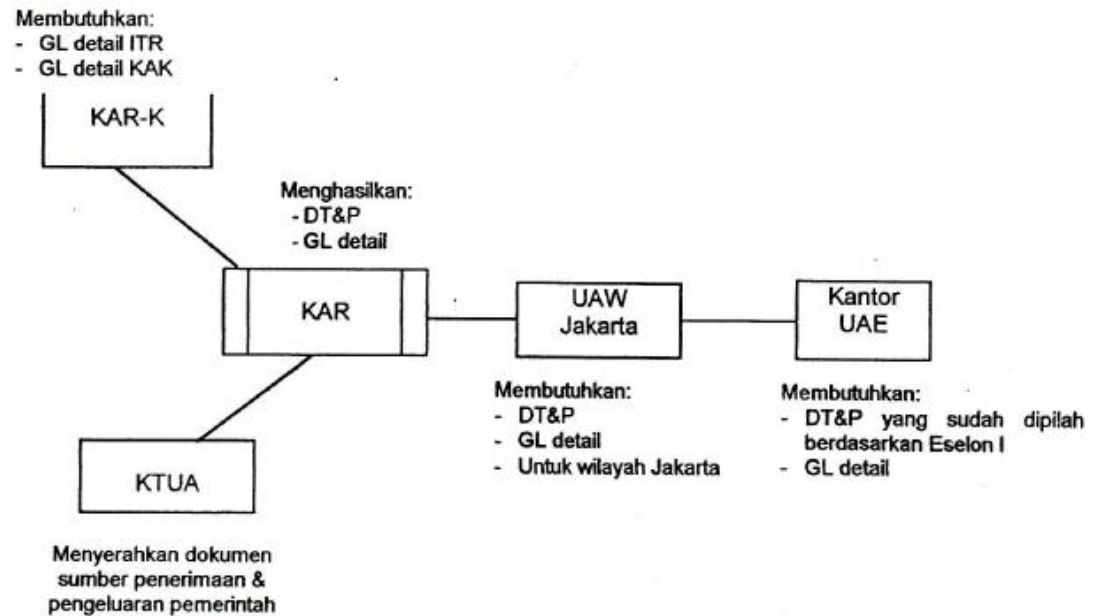

Gambar 1.14

Location Conectivity Diagram

Tujuan dari sistem KAR Jakarta adalah untuk menyediakan daftar transaksi dan posting (DT\&P) serta arsip data BB yang akurat dan benar bagi KP BAKUN, UAW, UAE untuk digunakan sebagai dasar pembuatan laporan keuangan tingkat kantor/proyek, laporan keuangan tingkat eselon, laporan keuangan tingkat departemen/instansi dan laporan keuangan pemerintah pusat. Tujuan tersebut amat berkaitan dengan tugas yang diemban oleh KAR yaitu melaksanakan akuntansi atas transaksi keuangan pemerintah di daerah berdasarkan peraturan perundang-undangan yang berlaku.

Dengan semakin banyaknya transaksi pengeluaran dan penerimaan pemerintah yang dilakukan oleh KPKN dilihat dari jumlah dokumen sumber yang masuk ke KAR Jakarta, maka persoalan-persoalan yang dihadapi oleh KAR Jakarta harus segara diatasi agar DT\&P serta arsip data BB yang dihasilkan oleh KAR menjadi lebih benar dan akurat. Masalah-masalah/kendala yang dihadapi oleh KAR terdiri dari masalah organisasi dan sistem informasi. Oleh karena itu masalah/kendala yang dihadapi tersebut 
akan dibahas berdasarkan sisi organisasi dan sistem informasi.

\section{$>$ Struktur Organisasi KAR}

Kantor Akuntansi Regional Jakarta terdiri dari 3 bagian yaitu sub bagian umum, seksi verifikasi dan seksi pengolahan data akuntansi (SPDA) serta seksi konsolidasi. Pembagian pekerjaan ke dalam 4 bagian ini sudah tepat karena sudah terjadi pemisahan antara fungsi penerimaan, pemeriksaan, pengolahan data serta penggabungan data. Akan tetapi karena jenis pekerjaan yang dilakukan adalah jenis pekerjaan yang rutin, membutuhkan ketelitian tinggi dan tidak bervariasi maka terjadi kejenuhan pada para pegawai KAR Jakarta. Hal ini menyebabkan hasil kerja para pegawai KAR Jakarta menjadi kurang memuaskan. Kondisi yang seperti ini ditambah dengan kurangnya motivasi dan tanggung jawab dari para pegawai terhadap tugas yangdiberikan kepada mereka menyebabkan hasil kerja KAR secara keseluruhan menjadi kurang baik. Mengingat fungsi yang dijalankan oleh KAR adalah fungsi yang sangat mendasar dan penting bagi pembuatan laporan keuangan yaitu antara lain menyediakan DT\&P dan ADK buku besar (GL detail) bagi UAW, UAE dan KP BAKUN serta mengirimkan GL entries ITR dan GL detail ke KAK maka situasi yang seperti ini harus segera ditangani.

Teori harapan dari Victor Vroom mengatakan bahwa seorang karyawan dimotivasi untuk menjalankan upaya yang tinggi bila ia meyakini upaya akan menghantar ke suatu penilaian Kinerja yang baik; suatu penitaian yang baik akan mendorong ganiarcnganiaran organisasional sepefii bonus, kenaikan gaji atau suatu promosi; dan ganiannganiann itu akan memuaskan tujuan-tujuan pibadi karyawan itu.

KAR Jakarta sebagai bagian dari organisasi yang lebih besar terikat kepada struktur organisasi Departemen Keuangan. Keputusan mengenai promosi, kenaikan gaji atau bonus ditentukan oleh pusat. Sangat sukar bagi KAR Jakarta untuk memberikan ganjaran-ganjaran organisasional kepada pegawainya. Langkah yang mungkin dapat dilakukan adalah melakukan rotasi pekerjaan secara berkala terhadap para pegawainya sehingga kejenuhan para pegawai agak berkurang. Langkah ini perlu dilakukan mengingat jenis pekerjaan yang dilakukan oleh pegawai KAR Jakarta adalah pekerjaan yang rutin dan membutuhkan ketelitian tinggi. Langkah lain yang perlu diambil adalah mengenai promosi pegawai. Promosi pegawai selama ini ditentukan oleh pusat tanpa melihat prestasi kerja pegawai. Akan lebih baik jika setiap instansi di bawah Departemen Keuangan mengirimkan daftar prestasi kerja para pegawainya peserta buktibuktiyang mendukung prestasitersebut ke pusat dan promosi akan dilakukan berdasarkan prestasi tersebut. Meskipun hal ini sulit untuk dilakukan tetapi para pegawai akan termotivasi dalam melakukan pekerjaannya karena masih memiliki harapan untuk menerima ganjaran promosi.

\section{$>$ Sistem lnformasi}

KAR Jakarta khususnya bagian SPDA menyadari bahwa sistem yang ada saat ini 
belum sempuma. Beberapa prosedur dan program yang dirasakan belum sempurna antara lain prosedur untuk penerimaan dokumen sumber, prosedur untuk verifikasi, prosedur untuk mencek SPP (Surat Permintaan Pembayaran) dan kegiatan yang dilakukan oleh tiap departemen/instansiyang mengajukan, dan program untuk konversi data dari DJA ke KAR yang belum sempuma sehingga data yang didapat dari hasil konversi tidak lengkap karena masih ada data yang lolos.

Untuk memecahkan masalah yang dihadapi, terdapat dua terdapat dua altematif untuk memecahkan masalah sistem di atas. pertama, menyusun sistem baru yang terpadu. Kedua, memperbaiki sistem yang ada dan mengganti dengan sistem yang sama sekali baru. Terpadu berarti meliputi seluruh bagian yang terkait dan terintegrasi. memperbaiki sistem yang ada berarti tetap mempertahankan sistem yang ada dan menambahkan beberapa prosedur yang sangat dibutuhkan serta memperbaiki beberapa prosedur yang kurang baik.

Untuk menentuan altematif mana yang harus dipilih, berikut ini akan dibahas kelebihan dan kekurangan dari masingmasing altematif pada tabel berikut.

\begin{tabular}{|c|c|c|}
\hline Alternatif & Kelebihan & Kelemahan \\
\hline $\begin{array}{l}\text { Menyusun } \\
\text { sislem yang } \\
\text { baru }\end{array}$ & $\begin{array}{l}\text { - Sistem yang, disusun dengan cara merombak } \\
\text { sistem yang sedang berjalan dan membuat } \\
\text { sistem yang sama sekali baru akan } \\
\text { menghasilkan sistem yang benar-benar } \\
\text { terpadu antara bagian-bagian/instansi- } \\
\text { instansi yang terkait. } \\
\text { - Informasi dapat dihasilkan dengan cepat } \\
\text { karena sistem yang terpadu }\end{array}$ & $\begin{array}{l}\text { - Untuk menyusun sistem yang terpadu } \\
\text { membutuhkan biaya yang sangat mahal, baik } \\
\text { unluk membayar pembual sistem maupun untuk } \\
\text { melengkapiralatan-peralatan } \\
\text { yangdibutuhkan. } \\
\text { - Untuk menyusun slstem tersebut diperlukan } \\
\text { waktu yang lama,karena skopenya luas. Sistem } \\
\text { KAR berhubungan dengan sistem lain seperti } \\
\text { slstem BAKUN, KAK, UAW, UAE, DJA, } \\
\text { KTUA, KPKN dan lain-lain. } \\
\text { - Keberhasilan suatu sistem untuk mencapai } \\
\text { tujuan pembentukan sistem sangat tergantung } \\
\text { kepada orang-orang yang nengoperasikan } \\
\text { sistem tersebul. Untuk menerapkan sistem yang } \\
\text { terintegrasi diperlulan banyak orang-orang } \\
\text { yang memiliki kemampuan yang sesuai dengan } \\
\text { tuntutan sistem tersebut. Saatini KAR Jakarta } \\
\text { belum memiliki orang-orang yang } \\
\text { berkemampuan demikian, sehingga jika akan } \\
\text { menerapkan sislem baru yang terpadu tersebut } \\
\text { perlu dikeluarkan biaya untuk pelatihan }\end{array}$ \\
\hline
\end{tabular}




\begin{tabular}{|c|c|c|}
\hline Alternatif & Kelebihan & Kelemahan \\
\hline & & pegawai-pegawainya \\
\hline $\begin{array}{l}\text { Memperbaiki } \\
\text { sistem yang } \\
\text { sudah ada }\end{array}$ & $\begin{array}{l}\text { - Jika dibandingkan dengan menyusun sistem } \\
\text { yang baru, memperbaiki slstem yang sudah } \\
\text { ada lebih murah biayanya korena skopenya } \\
\text { tidak luas sehingga biaya yang dikeluarkan } \\
\text { unluk membayar penyusun dan pengadaan } \\
\text { alat-alat yang diperlukan seperti komputer,dll } \\
\text { tidak terlalu banyak. } \\
\text { - Waktu yang diperlulan untuk memperbaiki } \\
\text { sistem tersebut relatif tidak lama larena } \\
\text { lingkupnya tidak luas. } \\
\text { - Pegawai yang perlu pelatihan untuk } \\
\text { menangani operasional dengan sistem ini } \\
\text { relatif sedikit dibandingkan dengan sistem } \\
\text { yang baru dan terpadu }\end{array}$ & $\begin{array}{l}\text { - Dengan hanya memperbaiki sistem yang ada di } \\
\text { KAR jakarta maka kelemahan operasional di } \\
\text { instansi lain yang terkait tidak teratasi. } \\
\text { - Informasi yang lengkap tidak dapat diperoleh } \\
\text { dengan cepat karena ada informasi dari terkait } \\
\text { yang harus } \\
\text { dikerjakan secara manual di lokasi yang terpisah- } \\
\text { pisah }\end{array}$ \\
\hline
\end{tabular}

Setelah mempertimbangkan kelebihan dan kekurangan dari setiap altematif sistem dan mempertimbangkan faktor biaya, waktu dan sumber daya manusia yang dimiliki oleh KAR Jakarta, maka peneliti mengambil altematif yang kedua yaitu memperbaiki sistem yang sudah ada sebagai sistem yang diusulkan. Berikut ini akan diuraikan usulan sistem bagi KAR Jakarta agar dapat menghasilkan output yang optimal.

\section{SOLUSI MASALAH}

\section{a. Usulan Sistem}

Untuk mengatasi masalah yang dihadapi oleh KAR Jakarta diberikan usulan sistem. Usulan sistem yang diberikan adalah berupa usulan perbaikan rancangan logik sistem bukan rancangan fisik. Berdasarkan analisis, maka untuk memperbaiki sistem yang sudah ada diperlukan langkah-langkah sebagai berikut:
- Memperbaiki prosedur penerimaan dokumen sumber.

Prosedur ini diperlukan untuk mengatasiketidaklengkapan dokumen sumbersehingga dapat diketahui secara pasti berapa pengeluaran dan pendapatanpemerintah pada suatu waktu tertentu.

- Memperbaiki prosedur untuk verifikasi

Prosedur ini diperbaikiagardata yang dihasilkan menjadilebih akurat.

- Memperbaiki ptosedur input data dokumen sumber yang tidak disertai ADK.

Prosedur ini perlu dibuat agar data yang dihasirkan menjadi rebih akurat.

- Membuat prosedur untuk mencek kesamaan antan kode kantor dan kode bagian anggaran pada SPM.

Prosedur ini diperlukan agar terdapat kesesuaian antara uang yang 
dikeluarkanoleh KPKN dan kegiatan yang dilakukan oleh instansiyang menerima.

- Membuat program konversi data yang lebih sempurna

Prosedur ini diperlukan mengingat KARJakarta menerima dokumen sumber dalam bentuk arsip data komputer dari sistemKTUA yang dibuat dengan bahasa pemrograman yang berbeda dengan bahasapemrogaman pada sistem KAR Jakarta. dengan demikian maka poses konversiyang dilakukan akan sempurna (tidak ada data yang lolos).

- Membuat diagnm sistem perbaikan

Diagram sistem perbaikan perlu dibuat agar proses perbaikan dapat dilihat.

\section{- Diagram Konteks}

Diagram konteks untuk Kantor Akuntansi Regional Jakarta mengalamiperubahan yaitu menjadi sebagai berikut:

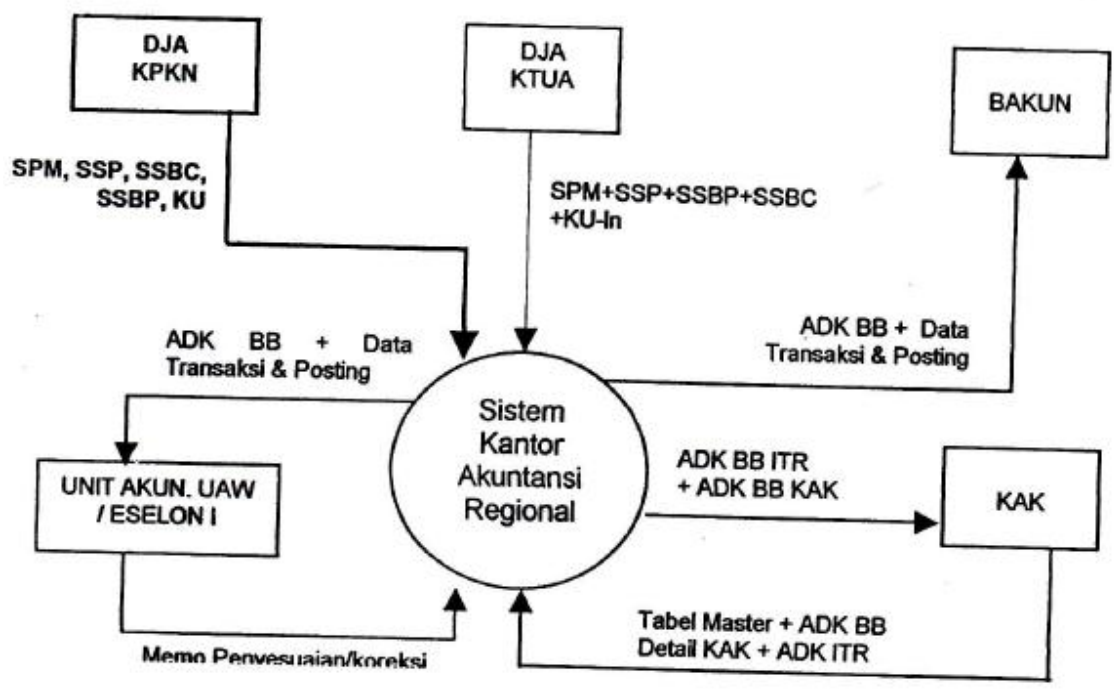

Gambar 1.15

Diagram Konteks Kantor Akuntansi Regional Jakarta

Dengan ditambahkannya extemal eentity DJA KPKN di atas maka sistem KAR Jakarta dapat menerima dokumen sumber langsung dari instansiyang menerbitkan/menerima dokumen sumber (KPKN) sehingga masalahketidaklengkapan dokumen sumber dapat segerateratasi.

\section{- Functional Decomposition Diagram}

Perubahan pada Functional Decomposition DiagramAkuntansi Regional adalah sebagai berikut terjaditransaksi CD dan transaksi CR. Sehingga menjadi: 


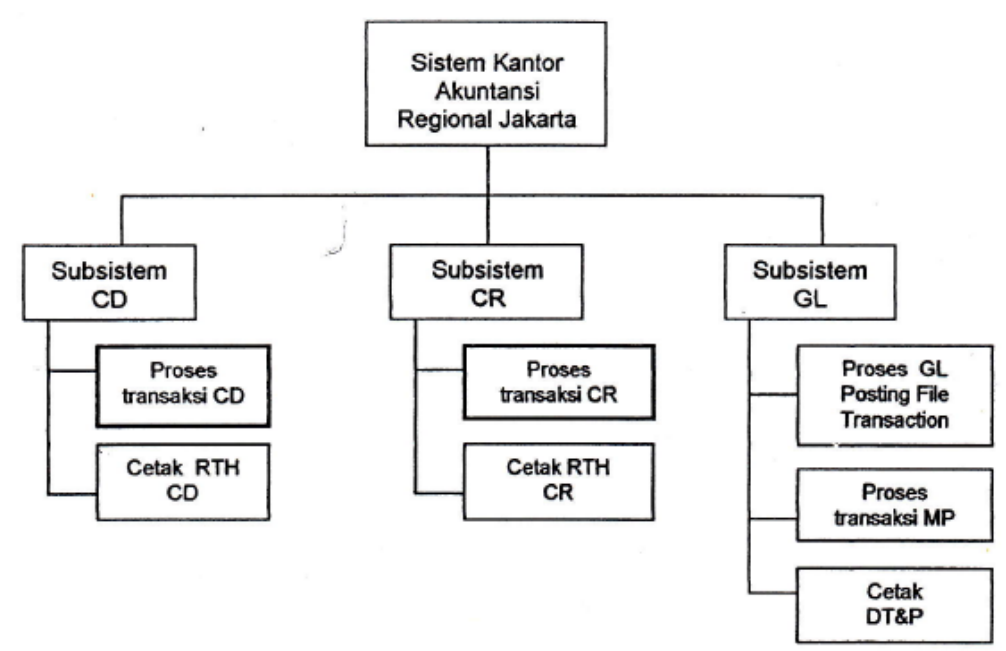

Gambar 1.16

Perubahan pada Functional Decomposition Diagram

Sistem Kantor Akuntansi Regional Jakarta

\section{- Event-Response List}

Perubahan yang terjadi untuk Event bisnis yang harus direspon serta responyang harus diberikan oteh Sistem Kantor Akuntansi Regional Jakarta adalah sebagaiberikut:

$\underline{\text { Subsistem Cash Disbursement }}$

\begin{tabular}{|c|l|}
\hline No. & \multicolumn{1}{|c|}{ Event } \\
\hline 1 & $\begin{array}{l}\text { KAR menerima informasi tabel master } \\
\text { dari Kantor Akuntansi Khusus (KAK). }\end{array}$ \\
\hline 2 & $\begin{array}{l}\text { Permintaan DS pengeluaran } \\
\text { pemerintah ke KPKN untuk DS yang } \\
\text { tidak lengkap. }\end{array}$ \\
\hline 3 & $\begin{array}{l}\text { KAR menerima ADK interface dan DS } \\
\text { dari KTUA }\end{array}$ \\
\hline 4 & $\begin{array}{l}\text { Sub bagian umum nremberikan catatan } \\
\text { pada seksi verifikasi dan SPDA tentang } \\
\text { DS pengeluaran pemerintah yang tidak } \\
\text { disertaa ADK. }\end{array}$ \\
\hline 5 & \begin{tabular}{l} 
SPDA mengkonversi clatra (ADK) \\
\hline
\end{tabular} \\
\hline
\end{tabular}

\begin{tabular}{|c|l|}
\hline No. & \multicolumn{1}{|c|}{ Event } \\
\hline & yang diterima dari Sub bagian Umurm. \\
\hline 6 & $\begin{array}{l}\text { Input data transaksi pengeluaran } \\
\text { pernerintah tanpa ADK di } \\
\text { minikomputer KAR Jakarta }\end{array}$ \\
\hline 7 & $\begin{array}{l}\text { DJA KPKN menyerahkan DS } \\
\text { pengeluaran pemerintah ke KAR. }\end{array}$ \\
\hline 8 & $\begin{array}{l}\text { Mencek kesamaan antara kode pos dan } \\
\text { kode bagian anggaran. }\end{array}$ \\
\hline 9 & $\begin{array}{l}\text { Seksi verifikasi mencocokkan DS } \\
\text { dengan RTH dan merecheck RTH yang } \\
\text { telah dicocokkan. }\end{array}$ \\
\hline 10 & SPDA memperbaiki RTH. \\
\hline 11 & $\begin{array}{l}\text { Seksi verifikasi meminta pembentukan } \\
\text { GL entries kepada SPDA. }\end{array}$ \\
\hline
\end{tabular}

$\underline{\text { Subsistem Cash Receipt }}$

\begin{tabular}{|c|c|}
\hline No. & \multicolumn{1}{|c|}{ Event } \\
\hline 1 & $\begin{array}{l}\text { KAR menerima informasi tabel master } \\
\text { dari Kantor Akuntansi Khusus (KAK). }\end{array}$ \\
\hline 2 & KAR menerima ADK interface dan DS \\
\hline
\end{tabular}




\begin{tabular}{|c|l|}
\hline No. & \multicolumn{1}{|c|}{ Event } \\
\hline & penerimaan pemerintah dari KTUA. \\
\hline 3 & $\begin{array}{l}\text { Permintaan DS penerimaan } \\
\text { pemerintah ke KPKN. }\end{array}$ \\
\hline 4 & $\begin{array}{l}\text { Sub bagian umum memberikan catatan } \\
\text { pada seksi verifikasi dan SPDA tentang } \\
\text { DS penerimaan pemerintah yang tidak } \\
\text { disertai ADK. }\end{array}$ \\
\hline 5 & $\begin{array}{l}\text { SPDA mengkonversi data (ADK) yang } \\
\text { diterima dari Sub bagian Umum. }\end{array}$ \\
\hline 6 & $\begin{array}{l}\text { Input data transaksi penerimaan } \\
\text { pemerintah tanpa AD di minikomputer } \\
\text { KAR Jakarta. }\end{array}$ \\
\hline 7 & $\begin{array}{l}\text { DJA KPKN menyerahkan DS } \\
\text { penerimaan pemerintah. }\end{array}$ \\
\hline 8 & $\begin{array}{l}\text { Seksi verifikasi mencocokkan DS } \\
\text { penerimaan pemerintah dengan RTH } \\
\text { dan merecheck RTH yang telah } \\
\text { dicocokkan. }\end{array}$ \\
\hline 9 & $\begin{array}{l}\text { Seksi verifikasi mencocokkan DS } \\
\text { penerimaan pemerintah dengan RTH } \\
\text { dan merecheck RTH yang telah } \\
\text { dicocokkan. }\end{array}$ \\
\hline 10 & SPDA memperbaiki RTH. \\
\hline 11 & $\begin{array}{l}\text { Seksi verifikasi } \\
\text { pembentukkan GL entries kepada } \\
\text { SPDA. }\end{array}$ \\
\hline
\end{tabular}

Subsistem General Ledger (tidak ada yang perlu disempurnakan/diubah)

\begin{tabular}{|c|l|}
\hline No. & \multicolumn{1}{|c|}{ Event } \\
\hline 1 & $\begin{array}{l}\text { KAR menerima informasi tabel master } \\
\text { dari Kantor Akuntansi Khusus (KAK). }\end{array}$ \\
\hline 2 & SPDA melakukan posting.. \\
\hline 3 & SPDA mencetak DT\&P. \\
\hline 4 & Seksi verifikasi membuat pengantar \\
\hline
\end{tabular}

\begin{tabular}{|c|l|}
\hline No. & \multicolumn{1}{|c|}{ Event } \\
\hline & ADK dan DT\&P untuk instansi. \\
\hline 5 & $\begin{array}{l}\text { Pencetakan register pengiriman GL } \\
\text { detail untuk KP BAKUN, UAW, dan } \\
\text { UAE oleh SPDA. }\end{array}$ \\
\hline 6 & $\begin{array}{l}\text { Ekspor file GL detail ke KP BAKUN, } \\
\text { KAK, UAW, dan UAE. }\end{array}$ \\
\hline 7 & $\begin{array}{l}\text { Memasukkan transaksi MP dari UAW } \\
\text { ke subsistem buku besar. }\end{array}$ \\
\hline 8 & Pemeriksaan RTH oleh seksi verifikasi. \\
\hline 9 & Pembentukan GL entries MP. \\
\hline 10 & Posting batch MP ke buku besar. \\
\hline
\end{tabular}

\section{- Network Modeling}

Berdasarkan analisa CSF maka network modeling untuk sistem KAR Jakarta menjadi sebagai berikut:

\section{a. Location Decomposition Diagram}

Tidak mengalami perubahan karena berdasarkan geografi yang dimiliki sislem KAR Jakarta tersebut tidak menimbulkan masalah.

\section{b. Location Conectivity Diagram}

Ada sedikit perubahan, yaitu dengan menambahkan hubungan ke sistem Kantor Perbendaharaan dan Kas Negara (KPKN). lni dilakukan untuk memecahkan masarah dokumen sumber yang tidak rangkap. Dokumen sumber yang dimaksud adalah dokumen sumber pengeluaran pemerintah, yaitu SPM dan dokumen sumber penerimaan pemerintah, yaitu:

- SSP untuk pendapatan dari penerimaan pajak, VAT receipt, 
rental tax receipt, dan penerimaan pajak lainnya.

- SSBC untuk pendapatan bea dan cukai

- SSBP untuk pendapatan bukan pajak, seperti pendapatan dari minyak, pendapatan sewa, pendapatan dari penjualan, dan pendapatan lainnya.

- SSBP UYHD untuk UYHD Rutin dan UYHD pembangunan.

- $\quad$ KU-In untuk transfer kas.
KTUA mendapat dokumen tersebut dari KPKN dan melaporkannya ke KAR Jakarta. Dengan ditambahkannya hubungan langsung ke KPKN maka dokumen sumber yang tidak ada dapat langsung ditanyakan ke KPKN sebagai instansi yang menerbitkan dan menerima dokumen sumber. Jika dokumen sumber sudah lengkap maka register transaksi harian dari KTUA yang telah dicetak oleh SPDA dapat segera dicocokkan dengan dokumen sumbemya sehingga data transaksi yang dihasilkan adalah data yang sah dan akurat

Selama ini KAR Jakarta hanya menerima dokumen sumber dari KTUA.

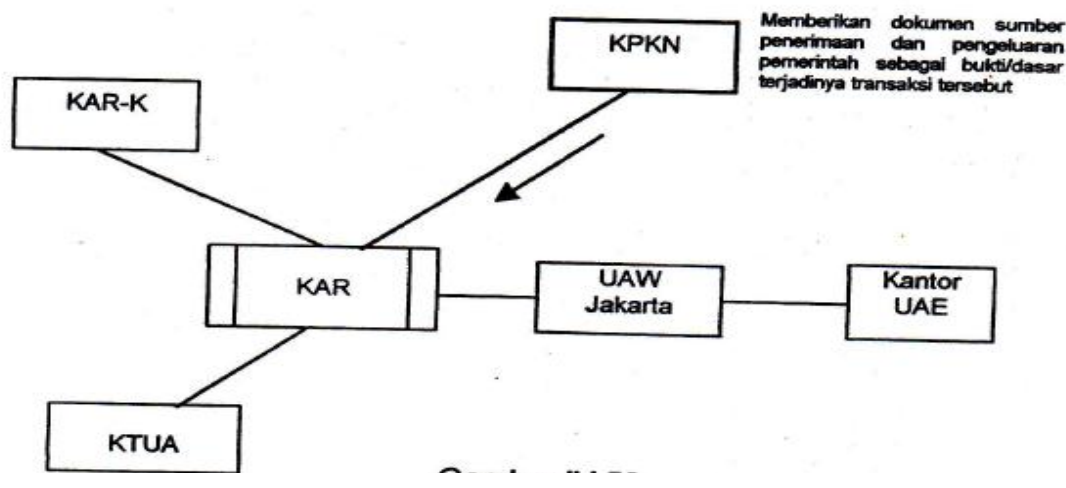

Gambar 1.17

Location Conectivity Diagram

\section{KESIMPULAN}

Berdasarkan hasil analisis terhadap Sistem Akuntansi pemerintah pusat di Kantor Akuntansi Regional Jakarta serta masalahmasalah yang dihadapi, maka dapat diambilkesimpulan sebagai berikut:

- Kantor Akuntansi Regional (KAR) adalah instansi vertikal BAKUN yang berada di bawah dan bertanggung jawab langsung kepada Kepala BAKUN. Dalam menyelenggarakan tugasnya KAR berfungsi sebagai pengumpulan dan verifikasi dokumen transaksi keuangan pemerintah, pengolahan data transaksi keuangan pemerintah, pendistribusian hasil pengolahan data akuntansi, pelaksanaan sistem akuntansi pusat, analisis laporan keuangan pemerintah, bimbingan teknis SAP termasuk Sistem Akuntansi Aset Tetap kepada unit-unit 
akuntansi diwilayah kerjanya, dan pelaksanaan administrasi KAR.

- KAR Jakarta menggunakan subsistemsubsistem cash disbursement (pengeluaran), cash receipt (penerimaan), dan general ledger (buku besar) untuk menjalankan fungsinya:.

- KAR Jakarta memiliki masalah/kendala dalam melaksanakan tugasnya, antara lain dokumen sumber yang tidak lengkap, vrifikasi data yang belum cermat, program konversi data yang digunakan masih kurang sempurna, elemen data SPM yang belum benar, dan kurangnya motivasi pegawai dalam menjalankan tugasnya.

- Dari hasil analisis Critical Success Fador (CSF) diperoleh bahwa aktifitas-aktifitas kunci yang harus dilakukan oleh KAR Jakarta agar dapat berhasil dalam melaksanakan tugasnya, yaitu menghasilkan data transaksi dan posting serta GL detail yang akurat dapat diidentifikasi maka KAR Jakarta harus memiliki dokumen sumber yang lengkap, pegawai yang memiliki motivasi tinggi datam menjalankan tugasnya, prosedur verifikasi yang baik, infrastruktur yang memadai pada instansi terkait serta memperbaiki sistem yang sudah ada.

- Berdasarkan hasil evaluasi terhadap aplikasi perangkat lunak sistem KAR Jakarta maka dapat diketahui bahwa aplikasi yang harus dipelihara, ditingkatkan, dan dikembangkan lebih lanjut adalah aplikasi $G L, C D$ dan
CRkarena memiliki nilai bisnis dan teknis yang tinggi. Aplikasi yang harus diperbarui adalah program konversi data karena memiliki nilai bisnis yang tinggi namun nilai teknisnya rendah.

- Dari hasil analisis terhadap proses yang terjadi pada slstem KAR Jakarta dengan menggunakan metode Data Flow Diagram (DFD) diketahui bahwa ada prosedur dan program yang harus dibuat ataupun diperbaiki. Prosedur-prosedur atau program harus diperbaiki adalah prosedur penerimaan dokumen sumber, prosedur untuk verifikasi, prcsedur input data dokumen sumber yang tidak disertai ADK, dan program konversi data. Prosedur baru yang harus dibuat adalah prosedur untuk mencek kesamaan antara kode kantor dan kode bagian anggann pada SPM.

Hasil analisis terhadap data sistem KAR Jakarta dengan menggunakan metodeEntity Relationship Diagram (ERD) menghasilkan Tabel relasional yang dapat digunakan untuk membuat usulan data untuk sistem berjalan. Hasil analisis terhadap struktur geografi sistem KAR Jakarta dengan menggunakan metode Network Modeling ditemukan bahwa dibutuhkan suatu hubungan antara KAR Jakarta dengan KPKN sebagai instansi yang menerbitkan dokumen sumber pengeluaran kas pemerintah dan penerima dokumen sumber penerimaan kas pemerintah. Hubungan dengan KPKN ini dibutuhkan agar ketidaklengkapan dokumen sumber yang diterima oleh KAR Jakarta dari KTUA dapat 
segera dilaporkan ke KPKN dan meminta KPKN untuk mengirimkan dokumen sumber yang dibutuhkan. Dengan demikian maka data transaksi yang dihasilkan dapat lebih dipertanggungjawabkan karena memiliki dokumen sumber sebagai bukti tedadinya transaksi.

\section{DAFTAR PUSTAKA}

Arinta, Kustadi, Pengantar Akuntansi Pemerintahan, Citra Aditya Bakti, Bandung, cetakan ke-4, ISBN/ISSN : 979-414-537-8, 1990

Badan Akuntansi dan Keuangan Negara, Komputerisasi sistem Akuntansi Pemerintah, Badan Akuntansi dan Keuangan Negara,1999

Badan Akuntansi dan Keuangan Negara, Modul Sistem Akuntansi pemerintah Pusat (SAPP) versi 2.0 untuk Lembaga, Badan Akuntansi dan Keuangan Negara, 1999

Badan Pendidikan dan Latihan Keuangan, Pengelolaan Keuangan Negara, Badan Pendidikan dan Latihan Keuangan, 1999

BAKUN, Prosedur Manual SAPP untuk KAR Jakarta: Buku Besar,BAKUN, 1999

BAKUN, Prosedur Manual SAPP untuk KAR Jakarta: Cash Disbursement, BAKUN,1999

BAKUN, Prosedur Manual SAPP untuk KAR Jakarta: Cash Receipt, BAKUN, 1999

BAKUN, Prosedur Manual SAPP untuk KAR Jakafta: Tabel Master, BAKUN, 1999

BAPPENAS, \& Departemen Keuangan, Petunjuk Teknis Pengisian DIP Tahun Anggaran 1999/2000, BAPPENAS dan Departemen Keuangan, 1999

Baswir, Revrison, Akuntansi Pemerintahan di Indonesia, UI Press, Jakarta, 2000

Bodnar, George M. \& Hopwood, William S., Accounting tnformation System, edisi 4, (Boston: Allyn \& Bacon), 1980

Connolly, Thomas E. \& Begg, Carolyn E., Strachan, Anne D., Database System, Addison Wesley Publishing Company, 1997

H.M.' Yogianto., Analisis \& Disain Sistem Informasi: Pendekatan Terstruktur Teori dan Praktek Aplikasi, Edisi kedua, cetakan pertama, (Penerbit Andi Yogyakarta), 1999

Harris, David, System Analysis \&̊ Design, Edisi2, (The Dryden Press), 1999 
KAR Jakarta, Urutan Kerja Pegawai KAR Jakarta, KAR Jakarta, 2000

Keputusan Menteri Keuangan No. 1135/KMK/01/1992 tentang Organisasi dan Tata Kerja Badan Akuntansi dan Keuangan Negara

Keraf, Gorys, Komposisi,cetakan ke.l1, Ende: penerbit Nusa indah,1997

Mulyadi, Sistem Akuntansi, edisi 3, Yogyakarta: Bagian Penerbitan Sekorah Tinggi Ilmu Ekonomi YKPN), 1997

Perry, James T., \& Schneider, Garry P., Building Accounting Systems, (South Westem College Publishing), 1995

PT Ernst \& Young Consulting, Report BAKUN: Cash Disbursement for GAS Release 2.0, PT Ernst \& Young Consulting, 1997

PT Ernst \& Young Consulting, Report BAKUN: Cash Receipt for GAS Release 2.0, PT Ernst $\&$ Young Consulting, 1997

PT Ernst \& Young Consulting, Report BAKUN: General Ledger for GAS Release 2.O, PT Ernst \& Young Consulting, 1997

PT Ernst \& Young Consulting, Report BAKUN: Master Tabel for GAS Release 2.0, PT Ernst \& Young Consulting, 1997

Robbins, Stephen, Organizational Behaviour, Prentice Hall, 1998

Romney, Marshall B. \& Steinbart, Paul John, Cushing, Barry E., Accounting Information System, Seventh Edition, Addison Wesley, 1997

Saputra, Gede, Sistem akuntansi pemerintahan di Indonesia, Jakarta PT.Gramedia, 2000

Sulaiman, Anita, Evaluasi Terhadap Sistem Pencatatan Akuntansi Pemerintah di Indonesia, unpublished Bachelor dissertation, Fakultas Ekonomi Universitas Indonesia, 1992

Turban, Efraim \& McLean. Efraim, Wetherbe, James, Information Technology for Management, john Wiley \& Son, 1996

Whitten, Jeffiey L. \& Bentley, Lonnie D, System Analysis and Design, fourth edition, (lrwin McGraw-Hill), 1999

Yusna, Dewi, Prospek dan Kendala Penerapan Sistem Akuntansi Pemerintah, www.mep.ugm.ac.id/kuliah/file.php/1/Artikel/Akuntansi_Pemerintah/mp082200128. pdf, 2001. 